\title{
Accelerated inflammation and oxidative stress induced by LPS in acute lung injury: Inhibition by ST1926
}

\author{
ZEWU DONG $^{*}$ and YUFANG YUAN* \\ Huai'an First People's Hospital, Nanjing Medical University, Huai'an, Jiangsu 223300, P.R. China
}

Received January 2, 2017; Accepted February 20, 2018

DOI: 10.3892/ijmm.2018.3574

\begin{abstract}
Bioavailable and less toxic synthetic retinoids, such as the atypical adamantyl retinoid ST1926, have been well developed and investigated in clinical trials for many diseases. The aim of our study was to explore the role of ST1926 in lipopolysaccharide (LPS)-induced acute lung injury (ALI) and to reveal the possible molecular mechanism. Mice were treated with LPS to induce acute lung injury followed by ST1926 administration. After LPS induction, mice administered with ST1926 showed lower inflammation infiltration in bronchoalveolar lavage (BAL) fluid, and pro-inflammatory cytokines, including interleukin-1 $\beta$ (IL-1 $\beta$ ), IL-18, IL-6 and tumor necrosis factor- $\alpha(\mathrm{TNF}-\alpha)$ in serum and lung tissue samples obtained from mice. In addition, western blot assays suggested that ST1926 suppressed nuclear factor $-\kappa B(N F-\kappa B)$, inhibitor- $\kappa \mathrm{B}$ kinase- $\alpha(\mathrm{I} \kappa \mathrm{B} \alpha)$ and $\mathrm{I} \kappa \mathrm{B}$ kinase $(\mathrm{IKK} \alpha)$, as well as Toll-like receptor 4 (TLR4) induced by LPS. In addition, reactive oxygen species (ROS) stimulated by LPS was also suppressed for ST1926 through inhibiting p38 and extracellular receptor kinase (ERK) signaling pathway. Taken together, the data here indicated that ST1926 may be of potential value in treating acute lung injury through inflammation and ROS suppression via inactivating TLR4/NF- $\kappa \mathrm{B}$ and $\mathrm{p} 38 / \mathrm{ERK} 1 / 2$ signaling pathways.
\end{abstract}

\section{Introduction}

Acute lung injury (ALI), and its more severe syndrome, acute respiratory distress syndrome (ARDS), is pulmonary inflammation with devastating disorders, leading to diffuse alveolar damage, which causes hypoxemia, pulmonary edema as well as respiratory failure $(1,2)$. The pediatric ALI incidence is

Correspondence to: Dr Zewu Dong, Huai'an First People's Hospital, Nanjing Medical University, 6 Beijing Road West, Huai'an, Jiangsu 223300, P.R. China

E-mail: qlc_2@163.com; dongzewuha@foxmail.com

*Contributed equally

Key words: ST1926, acute lung injury, inflammation, reactive oxygen species high in developed countries (3). ALI is related to pediatric intensive care unit admissions, which causes an increasing of pediatric intensive care unit deaths (4). Previous studies for children and adults exhibit strong relationship between positive fluid balance and the worse outcomes, such as death, in patients with respiratory failure and/or ALI $(5,6)$. In addition, a previous study indicated that the percentage of fluid overload has a close relationship with worse oxygenation, enhanced duration of mechanical ventilation, as well as increasing of hospital length stay (7). In children with ALI accordingly, only some of them were successfully being treated to prevent fluid overload $(8,9)$. Thus, finding effective method and exploring the molecular mechanism are necessary.

Inflammatory response is the common pathological process, contributing to many diseases, which are regulated by nuclear factor- $\kappa \mathrm{B}(\mathrm{NF}-\kappa \mathrm{B})$ signaling pathway (10). As previously reported, TLR family plays an important role in pathogen recognition and activation of innate immunity (11). Once activated by stimuli, TLRs family performs corresponding response by stimulating a cascade of various distinct events. The TLRs in a variety of formations exhibit different patterns for expression. Accumulating evidence has showed that Toll-like receptor 4 (TLR4), stimulated by lipopolysaccharide (LPS), can induce acute lung injury by activating TLR4/NF- $\kappa \mathrm{B}$, associated with inflammation response (12-14). Additionally, reactive oxygen species (ROS) are linked to many diseases, such as diabetes, heart injury, liver injury and renal dysfunction. The species of ROS involve molecular oxygen, such as superoxide $\left(\mathrm{O}_{2}^{-}\right)$and hydrogen peroxide $\left(\mathrm{H}_{2} \mathrm{O}_{2}\right)$. Excessive $\mathrm{O}_{2}{ }^{-}$and $\mathrm{H}_{2} \mathrm{O}_{2}$ produce signaling responses, disrupting cellular processes and leading to tissue injury (15).

Retinoids regulate vital biological processes, including cellular proliferation, inflammation, apoptosis, and differentiation (16-18). However, bioavailable and less toxic synthetic retinoids, such as the atypical adamantyl retinoid ST1926, have been developed and tested in clinical trials (19). For example, ST1926 showed potential efficacy on solid tumors and hematological malignancies with minimal side effects or toxicity (20). Further, oral ST1926 is pharmacokinetically stable, bioavailable and pharmacologically attainable in the plasma of patients $(21,22)$. Although this compound has been investigated in phase 1 clinical trials, it is still little known in acute lung injury treatment, especially from inflammation and ROS suppression. We explored the efficacy of ST1926 in acute lung injury models in vivo and in vitro to investigate its 
underlying pharmacological mechanisms, which may be of potential value for acute lung injury treatment in children.

\section{Materials and methods}

Animal treatment. Sixty male, 6-week-old C57BL6 mice, weighing 20-22 g were purchased from experimental animal center of Nanjing Medical University of laboratory animal center. All the mice were carefully maintained at room temperature on a 12:12 h light:dark cycle, with free access to chow and water in the cages. This study was approved by the Ethics Committee on Animal Research at the Department of Pediatrics, Huai'an First People's Hospital, Nanjing Medical University, Nanjing, China. The mice were divided into 4 groups: the control group without LPS and ST1926 administration (Con, $\mathrm{n}=15)$; LPS-induced group $(15 \mathrm{mg} / \mathrm{kg}$, $\mathrm{n}=15) ; 10 \mathrm{mg} / \mathrm{kg}$ ST1926-treated group after LPS treatment (ST1926/L, n=15); $20 \mathrm{mg} / \mathrm{kg}$ ST1926-treated group after LPS (ST1926/H, n=15) (23). After 7 days adaptation, mice from LPS group were treated by intraperitoneal injection with $15 \mathrm{mg} / \mathrm{kg}$ body weight LPS for $6 \mathrm{~h}$. The control group was also administered with the same volume of Hanks' buffer. Then, the mice were administered with different concentrations of ST1926 via oral gavage for 2 weeks. The suspension was mixed in high concentration for use immediately after it was ready within $1 \mathrm{~min}$ through oral gavage. ST1926, purchased from Sigma-Tau and Biogem (Ariano Irpino, Italy) was dissolved in distilled water. Then, all the mice were sacrificed. Eyeball blood was collected for the next investigation, and the whole lung tissues were carefully harvested on $4^{\circ} \mathrm{C}$ glacial table.

Cell culture. Mouse lung epithelial cells, MLE-12, and human bronchial epithelial cells (NHBE) were obtained from Shanghai Haoran Biological Technology Co., Ltd. (Shanghai, China) and both cultured in Dulbecco's modified Eagle's medium (DMEM)/F12 containing 1\% penicillin/streptomycin and $10 \%$ fetal bovine serum (FBS). All cells were cultured in a humidified atmosphere with $5 \% \mathrm{CO}_{2}$ and $95 \%$ humidity at $37^{\circ} \mathrm{C}$ in an incubator. Cells were treated with $100 \mathrm{ng} / \mathrm{ml}$ LPS with or without different concentrations $(4 \mu \mathrm{M}, \mathrm{ST} 1926 / \mathrm{L}$; $8 \mu \mathrm{M}, \mathrm{ST} 1926 / \mathrm{H})$ of ST1926 for $24 \mathrm{~h}$.

3-(4,5-Dimethylthiazol-2-yl)-2,5-diphenyl-2H-tetrazolium bromide (MTT) assays. Lung epithelial cells $\left(5 \times 10^{3}\right)$ were planted into a 96-well plate (Corning Inc., Corning, NY, USA) per well. ST1926, from 0-8 $\mu \mathrm{M}$, was added to the medium for $24 \mathrm{~h}$. The cells were then incubated at $37^{\circ} \mathrm{C}$ in an incubator, and the cell viability was detected by the colorimetric MTT assay at $570 \mathrm{~nm}$ following the manufacturer's instructions (KeyGen Biotech, Nanjing, China).

Biochemical analysis. Levels of superoxide dismutase (SOD), Catalase (CAT) and malondialdehyde (MDA) in serum and lung tissue samples were determined by commercially available kits (Nanjing Jiancheng Bioengineering Institute, Nanjing, China) according to the manufacturer's instructions.

The serum tumor necrosis factor- $\alpha$ (TNF- $\alpha$, MTA00B), interleukin-1 $\beta$ (IL-1 $\beta$, MLB00C) (both from R\&D Systems, Minneapolis, MN, USA), IL-8 (BYL02382; Beinglay,
Wuhan, China), IL-18 (DY122-05), IL-5 (M5000) (both from R\&D Systems), IL-6 (BMS603; Bender MedSystems, Vienna, Austria), IL-12 (PK-EL-62216M; Promocell, Heidelberg, Germany), IL-10 (M1000B; R\&D Systems), and IL-17 (BMS6001; Bender MedSystems) were measured according to the manufacturer's protocol using an enzyme-linked immunosorbent assay (ELISA) kit. For the determination of cytokine levels, blood samples from the rats were obtained after sacrifice and stored at $-80^{\circ} \mathrm{C}$ until use.

$\mathrm{H}_{2} \mathrm{O}_{2}$ levels in lung tissue were detected using a hydrogen peroxide assay kit (catalase assay kit, S0051; Beyotime Institute of Biotechnology, Jiangsu, China) following the manufacturer's instructions. $\mathrm{O}_{2}^{-}$of lung tissue samples was measured by lucigenin chemiluminescence method. Briefly, lung tissue of mice under different conditions were weighed and homogenized in a homogenization buffer using Hepes and EDTA. After centrifugation, an aliquot of the supernatant was incubated with $5 \mu \mathrm{M}$ lucigenin in Krebs-Hepes buffer. Light emission was measured with a Tecan Infinite 200. Specificity for $\mathrm{O}_{2}{ }^{-}$was evaluated by adding $350 \mathrm{U} / \mathrm{ml} \mathrm{SOD}$ to the incubation medium. Protein concentration was assessed with BCA Protein Quantitative analysis kit (Thermo Fisher Scientific, Waltham, MA, USA).

Inflammatory cell counts of BALF. After treatment, eight mice in each group were sacrificed and BALF was obtained by washing three times with $1 \mathrm{ml}$ of cold sterile phosphate-buffered saline (PBS) through a tracheal cannula. BALF samples were centrifuged at $3,000 \mathrm{rpm}$ for $10 \mathrm{~min}$ at $4^{\circ} \mathrm{C}$, and the cell pellet was resuspended in PBS for the total cell number assessment with a hemacytometer, and the cytospins were prepared for other differential cell number through staining with the method of Wright-Giemsa staining. Percentages of BALF macrophages, neutrophils and lymphocytes were obtained by counting leukocytes under light microscopy.

Measurement of NOx levels. Mouse lung tissue lysates were treated with cold ethanol for $1 \mathrm{~h}$ at $-20^{\circ} \mathrm{C}$ and then centrifuged at $20,000 \mathrm{x}$ g to remove proteins that can interfere with $\mathrm{NO}$ measurements. The potassium iodide-acetic acid reagent was prepared fresh by dissolving $0.05 \mathrm{~g}$ of potassium iodide in $7 \mathrm{ml}$ of acetic acid. The KI/AcOH mixture was added into a septum-sealed purge vessel and bubbled with nitrogen gas. The gas stream was connected via a trap containing $1 \mathrm{~N}$ $\mathrm{NaOH}$ to a Sievers 280i Nitric Oxide Analyzer (GE Analytical Instruments, Boulder, CO, USA). The samples were injected with a syringe through a silicone-Teflon septum. The data were then analyzed via assessing the area under the curve of chemiluminescence signal with the Liquid software (GE Analytical Instruments). The resultant NOx value presents the total nitric oxide and nitrite in pmols $/ \mathrm{mg}$ protein.

Myeloperoxidase (MPO) activity. MPO activity in mouse lung tissue was determined using MPO assay kit (BioVision, Milpitas, CA, USA) following the manufacturer's instructions. Briefly, the MPO in the samples catalyzes the production of $\mathrm{NaClO}$ from $\mathrm{H}_{2} \mathrm{O}_{2}$ and $\mathrm{NaCl}$. Next, the $\mathrm{NaClO}$ reacts with exogenously added aminophenyl fluorescein to generate fluorescein, which is assessed with a fluorometer at $485 \mathrm{~nm}$ excitation and $525 \mathrm{~nm}$ emission. The relative fluorescent units 
of each sample are converted into pmol of fluorescein by a standard curve. The data are reported as pmol fluorescein generated $/ \mathrm{min} / \mathrm{mg}$ of protein extract.

Immunohistochemical (IHC) analysis. The lung and liver tissue samples were fixed using $10 \%$ buffered formalin, imbedded in paraffin and then sliced into $4 \mu \mathrm{M}$ thick sections. Following the hematoxylin and eosin (H\&E) staining, the pathological alterations of the lung tissue samples were observed under a light microscope. Periodic acid-Shiff (PAS) staining was performed using a standard protocol. The number of PAS positive cells was quantified by inspection by a single-blinded investigator. Individual slides were examined independently. Lung tissue samples were IHC stained for the analysis of the lung tissue after different treatments. The sections were stained with TNF- $\alpha$ and IL-1 $\beta$ (Abcam, Cambridge, MA, USA) overnight at $4^{\circ} \mathrm{C}$, prior to incubation according to the manufacturer's instructions, followed by horseradish peroxidase conjugated anti-rabbit IgG (Dako, Glostrup, Denmark) as a secondary antibody.

Fluorescence imaging. Lung tissue sections and cells were washed twice with PBS and fixed with $3.7 \%$ (v/v) formaldehyde in PBS for $15 \mathrm{~min}$. Cells were permeabilised for $5 \mathrm{~min}$ with $0.1 \%$ Triton $\mathrm{X}-100$, then they blocked with $1 \%$ bovine serum albumin for $30 \mathrm{~min}$. For TLR4 and $\mathrm{p}-\mathrm{NF}-\kappa \mathrm{B}$ staining in tissue and cell respectively, $50 \mu \mathrm{g} / \mathrm{ml}$ mouse anti-p-NF- $\kappa \mathrm{B}$ and TLR4 antibodies were employed at $4^{\circ} \mathrm{C}$ overnight, followed by staining with $2 \mu \mathrm{g} / \mathrm{ml}$ Alexa Fluor 488-goat anti-mouse secondary antibodies at room temperature. 4',6-Diamidino-2-phenylindole (DAPI; Sigma-Aldrich) were used. Images were acquired by confocal laser scanning (Leica TCS SP5; Leica, Heidelberg, Germany) by epifluorescence microscopy (Ningbo Sunny Instruments Co., Ltd., Ningbo, China).

Real-time quantitative polymerase chain reaction $(R T-q P C R)$ and western blot assays. Total RNA was extracted from lung tissue samples and cells by using TRI-reagent (Sigma-Aldrich) following the manufacturer's instructions and treated with deoxyribonuclease I. Then the mRNA was converted into cDNA for real-time PCR analysis. Real-time PCR was carried out $\left(35\right.$ cycles of $95^{\circ} \mathrm{C}$ for $20 \mathrm{sec}, 54^{\circ} \mathrm{C}$ for $30 \mathrm{sec}$, and $72^{\circ} \mathrm{C}$ for $30 \mathrm{sec}$ ). Fold alterations in mRNA levels of the targeting gene relative to the endogenous cyclophilin control were calculated. Briefly, the cycle threshold $(=\mathrm{Ct})$ values of each target gene were subtracted from the $\mathrm{Ct}$ values of the housekeeping gene cyclophilin $(\Delta \mathrm{Ct})$. Targeting gene $\Delta \Delta \mathrm{Ct}$ was calculated as $\Delta \mathrm{Ct}$ of target gene minus $\Delta \mathrm{Ct}$ of control. The fold change in mRNA expression was calculated as $2^{-\Delta \Delta \mathrm{Ct}}$ following a previous study. The sequences used in this study are as follows: forward IL-18, (5'-3') TAA GGA TAC GGA CTA CGG CT and reverse primers, (5'-3') GTT GGT GGA GGT CTG AGT TTA; forward IL-6, (5'-3') ACT ACT TATC GTC GAG GTG CTA T and reverse primers, (5'-3') CGA GCT TGG AGT ACC ATG TTA CTT; forward TNF- $\alpha,\left(5^{\prime}-3^{\prime}\right)$ ATA GGA ACC AGG GGC AGT T and reverse primers, (5'-3') CTG CGT TCA GAT GAT TGA TG; forward SOD1, (5'-3') CTG GCC TGC TCT GCT GCT TGT and reverse primers, (5'-3') TGG TAG GTG CGG ACT GTG GT; forward SOD2, (5'-3') CCT TGC GTC ATT CTA TCC A and reverse primers, (5'-3') GAA ACG CGC
CAG AAG GGT TA; forward TLR4, (5'-3') CTG CTG CCT GCT TGC TGC GT and reverse primers, (5'-3') GTG GTG TGT GCG GTG TAG AC; forward MyD88, (5'-3') CAC TTC GCT GTC ATC TCC A and reverse primers, (5'-3') AGC ACA GAG CGT CAA GAG GT; forward CAT, (5'-3') CTC TCT GTG ACC GTA ACG CTG GT and reverse primers (5'-3') TGC GTG TGG TGC GTG ATG GAG ACC; forward haeme oxygenase-1 (HO-1), (5'-3') CTA GCT TCG TGC ACA GCT GCG T and reverse primers, (5'-3') GTG ATG ACT GCG CGT GGT GCT AGA AC; forward Nrf2, (5'-3') CTC TCT GGA CCT TCC GTT GCG CTG T and reverse primers, (5'-3') GTT GTA GGT CAG TGT TCG AGG ATC; forward TGF- $\beta 1,\left(5^{\prime}-3^{\prime}\right)$ AGG AAC TAC GCA GTG GGA T and reverse primers, (5'-3') CGT CTG TCA GAT GAA TGT TG; forward Foxp3, (5'-3') GCC TCT GGC TTG TCT GCT CTG and reverse primers (5'-3') GGT ATG GAG TGC GTG ATG TCT G; forward interferon $\gamma$ (IFN $\gamma),\left(5^{\prime}-3^{\prime}\right)$ GCG CTC ATC TCC TCA TAC TAT and reverse primers, (5'-3') GAA CCA GCC CGG AGA CAG TTG A; forward granzyme B (GzmB), (5'-3') CCT GAG TCT GAC TGT CGC CAT GT and reverse primers, (5'-3') GTG TCT GAG TAC TTG GAC GTA; forward Tbx-21, (5'-3') CAC GTG CTG CTA GCT GGT GCT CAT and reverse primers, (5'-3') GTC ATG TGC ATG ATA GAT AC; forward glyceraldehyde 3-phosphate dehydrogenase (GAPDH), (5'-3') CTA AGT CGA ATG CAA ACA GTT CAG and reverse primers, (5'-3') AAC ATA CCA TCC ACG ACA CGC TC, which was used as the loading control.

In immunoblotting, lung tissue samples and epithelial cells were homogenized into $10 \%$ (wt/vol) hypotonic buffer (25 mM Tris-HCl, pH 8.0, 1 mM EDTA, $5 \mu \mathrm{g} / \mathrm{ml}$ leupeptin, $1 \mathrm{mM}$ Pefabloc SC, $50 \mu \mathrm{g} / \mathrm{ml}$ aprotinin, $5 \mu \mathrm{g} / \mathrm{ml}$ soybean trypsin inhibitor, $4 \mathrm{mM}$ benzamidine) to yield a homogenate. Then the final supernatants were obtained by centrifugation at $12,000 \mathrm{rpm}$ for $20 \mathrm{~min}$. Protein concentration was determined by BCA protein assay kit (Thermo Fisher Scientific) with bovine serum albumin as a standard. Then, same amount of total protein were clapped into $10 \%$ sodium dodecyl sulfate-polyacrylamide gel electrophoresis (SDS-PAGE) followed by immunoblotting using the following antibodies: rabbit anti-p-NF- $\kappa \mathrm{B}(1: 1,000), \mathrm{NF}-\kappa \mathrm{B}(1: 1,000)$ (both from Abcam), SOD1 (1:1,000), SOD2 (1:1,000), TLR4 (1:1,000), MyD88 (1:1,000) (all from Cell Signaling Technology), p38 $(1: 1,000)$, p-p38 $(1: 1,000)$, extracellular receptor kinase $1 / 2$ (ERK1/2) $(1: 1,000)$, p-ERK1/2 $(1: 1,000)$, inhibitor- $\kappa B$ kinase $(\mathrm{IKK} \alpha)(1: 1,000)$, inhibitor- $\kappa \mathrm{B}$ kinase- $\alpha(\mathrm{I} \kappa \mathrm{B} \alpha)(1: 1,000)$, TGF- $\beta 1$ (1:1,000), Foxp3 (1:1,000), IFN $\gamma(1: 1,000)$, CAT $(1: 1,000)$ (all from Abcam), HO-1 (1:1,000; Cell Signaling Technology), Nrf2 (1:1,000; Abcam), GzmB (1:1,000; Cell Signaling Technology), Tbx-21 (1:1,000; Abcam), and GAPDH (1:500; Santa Cruz Biotechnology, Inc., Santa Cruz, CA, USA). Western blot bands were observed using GE Healthcare ECL western blotting analysis system and exposed to Kodak X-ray film. Each protein expression level was defined as grey value (version 1.4.2b, Mac OS X, ImageJ; National Institutes of Health, Bethesda, MA, USA) and standardized to housekeeping genes (GAPDH) and expressed as a fold of control.

Statistical analysis. Data are expressed as the means \pm SD. The treated tissues, cells, and corresponding controls were 

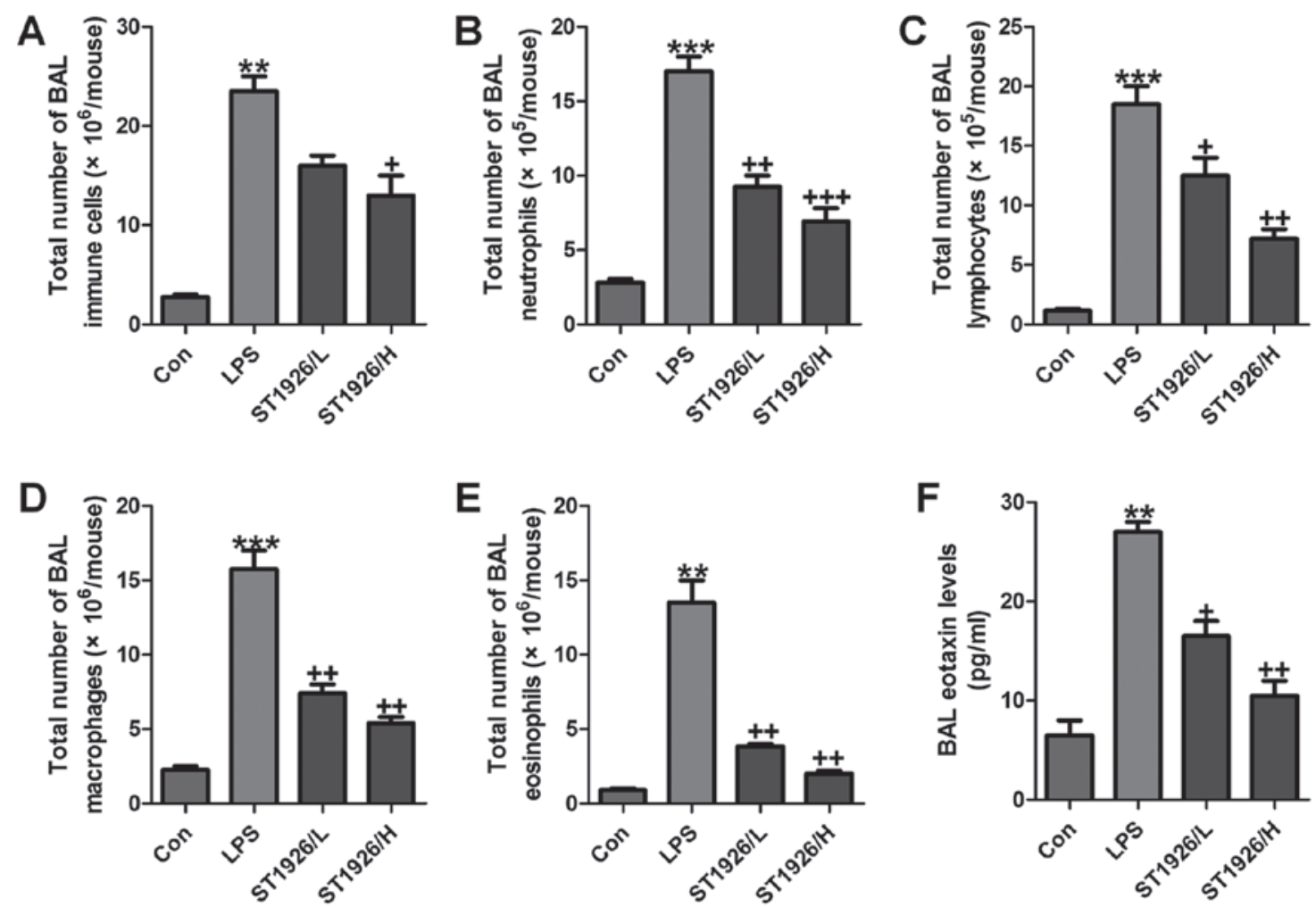

Figure 1. ST1926 reduces inflammatory cell infiltrate in lipopolysaccharide (LPS)-induced mice with acute lung injury. The number of cells in inflammation infiltration was determined. (A) Total cells, (B) total neutrophils, (C) total lymphocytes, (D) total macrophages, and (E) total eosinophils. (F) Eotaxin levels in bronchoalveolar lavage (BAL) were assessed. The data are represented as mean $\pm \mathrm{SD}(\mathrm{n}=8) .{ }^{*} \mathrm{p}<0.05$ and ${ }^{* *} \mathrm{p}<0.001 \mathrm{vs}$. the control $(\mathrm{Con}) ;{ }^{+} \mathrm{p}<0.05,{ }^{++} \mathrm{p}<0.01$ and ${ }^{+++} \mathrm{p}<0.001$ vs. LPS-induced mice (LPS).

compared using GraphPad PRI SM (version 6.0; GraphPad Software, La Jolla, CA, USA). Significant differences between groups were considered at $\mathrm{p}<0.05$.

\section{Results}

ST1926 reduces inflammatory cell infiltrate in LPS-induced mice with acute lung injury. As an index reflecting airway inflammation, here the role of ST1926 in inflammation regulation was investigated. First, the bronchoalveolar lavages (BAL) was conducted and explored. As shown in Fig. 1A, LPS treatment resulted in an elevation of the total number of BAL, contributing to an acceleration of neutrophils (Fig. 1B), lymphocytes (Fig. 1C), macrophages (Fig. 1D), and eosinophils (Fig. 1E). Of note, ST1926 significantly reduced the total number of BAL, as well as neutrophils (Fig. 1B), lymphocytes (Fig. 1C), macrophages (Fig. 1D), and eosinophils (Fig. 1E), in a dose-dependent manner. Additionally, in the lung tissue samples with LPS induction, BAL eotaxin was apparently decreased, which was attenuated by ST1926 treatment (Fig. 1F).

LPS-induced acute lung injury in mice is ameliorated by ST1926 administration. LPS induction is well known to cause injury in different organs, including the liver, renal injury and heart, even the lung, as explored previously (24). Here, in order to assess whether ST1926 has potential effects on airway inflammation in children, LPS was used to induce acute lung injury. In this regard, H\&E staining was carried out to observe the injuries of lung tissue specimens. Fig. 2A and B shows, that after LPS treatment in mice, the lung tissue sample showed higher inflammation score compared to the Con group, which was comparable. After ST1926 treatment, the inflammatory response was attenuated markedly. In addition, PAS analysis also exhibited that the percent of PAS positive cells was notably upregulated by LPS exposure, whereas reversed in ST1926 administration in a dose-dependent manner (Fig. 2C and D). The data above indicated that ST1926 exhibited protective role against the LPS-induced acute lung injury in mice.

In order to further confirm that ST1926 could attenuate LPS-caused lung injury via inflammation improvement, proinflammatory cytokines level in serum were measured. As shown in Fig. 3, we found that pro-inflammatory cytokines of TNF- $\alpha$ (Fig. 3A), IL-6 (Fig. 3B), IL-5 (Fig. 3C), IL-1 3 (Fig. 3D), IL-18 (Fig. 3E) and IL-17 (Fig. 3F) in serum were considerably stimulated in mice with LPS exposure. In agreement with the results as mentioned above, ST1926 displayed suppressive role in the inflammatory cytokine secretion, suggesting that ST1926, at least partly, improved LPS-induced injury from inflammation inhibition.

TGF- $\beta 1$ is one of the most studied cytokines that play an essential role in induction and development of acute injury, contributing to the inflammatory cell recruitment (25). GzmB is a serine protease with intracellular and extracellular activities capable of regulating inflammation through cytokine processing and apoptosis of effector cells (26). We tested the hypothesis that TGF- $\beta 1$ and GzmB will be changed in LPS treatment, and ST1926 may have potential to reverse 

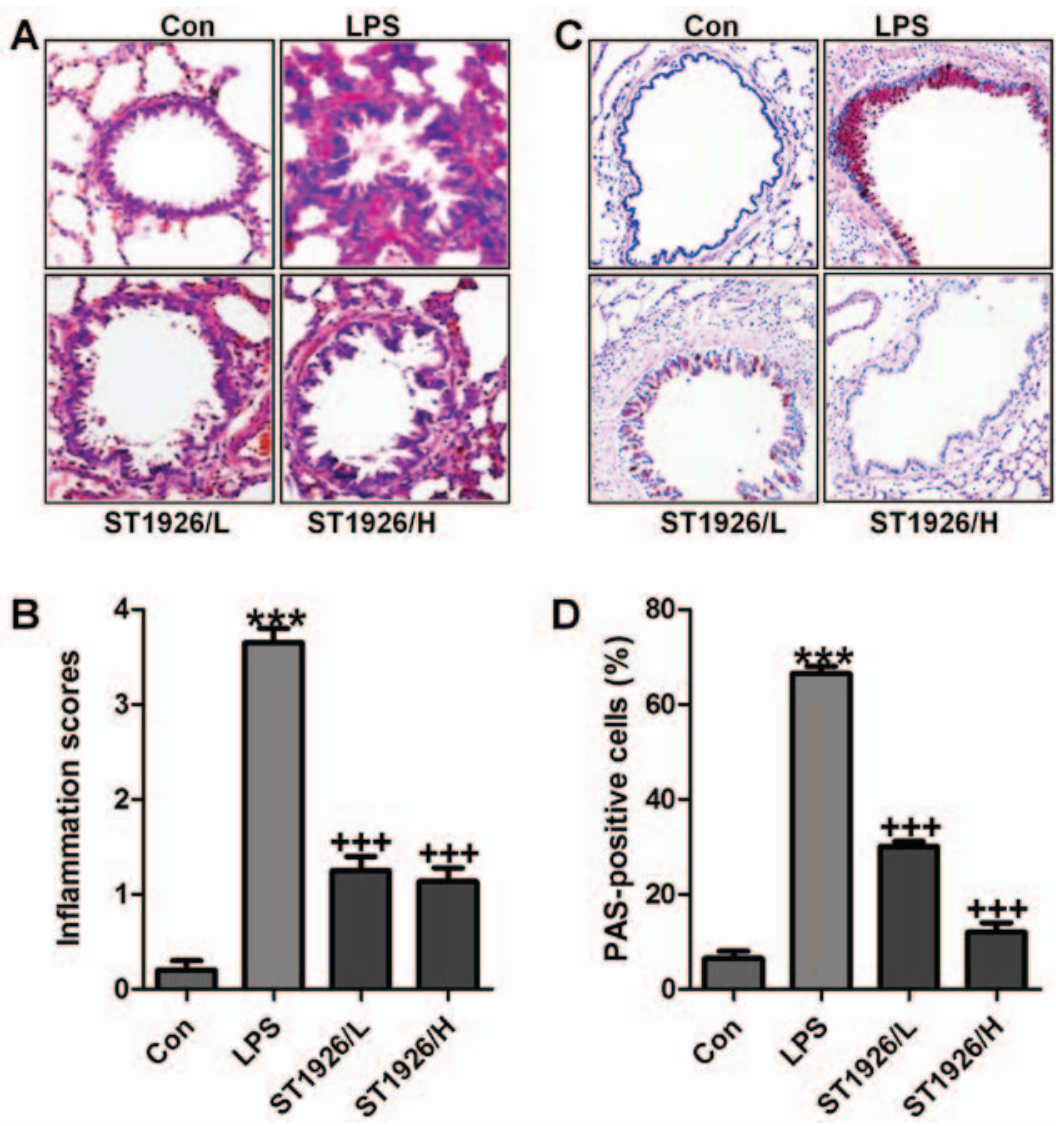

Figure 2. Lipopolysaccharide (LPS)-induced acute lung injury in mice is ameliorated by ST1926 administration. (A) The representative images of lung injury are shown by hematoxylin and eosin (H\&E) staining. (B) The quantification of inflammatory response following H\&E staining. (C) PAS staining was used to observe goblet cells in LPS-induced mice with acute lung injury. (D) The quantification of PAS-positive cells. The data are presented as mean \pm SD ( $n=8$ ). ${ }^{*} \mathrm{p}<0.05$ and ${ }^{* *} \mathrm{p}<0.001$ vs. the control (Con); ${ }^{+} \mathrm{p}<0.05,{ }^{++} \mathrm{p}<0.01$ and ${ }^{+++} \mathrm{p}<0.001$ vs. LPS-induced mice (LPS).
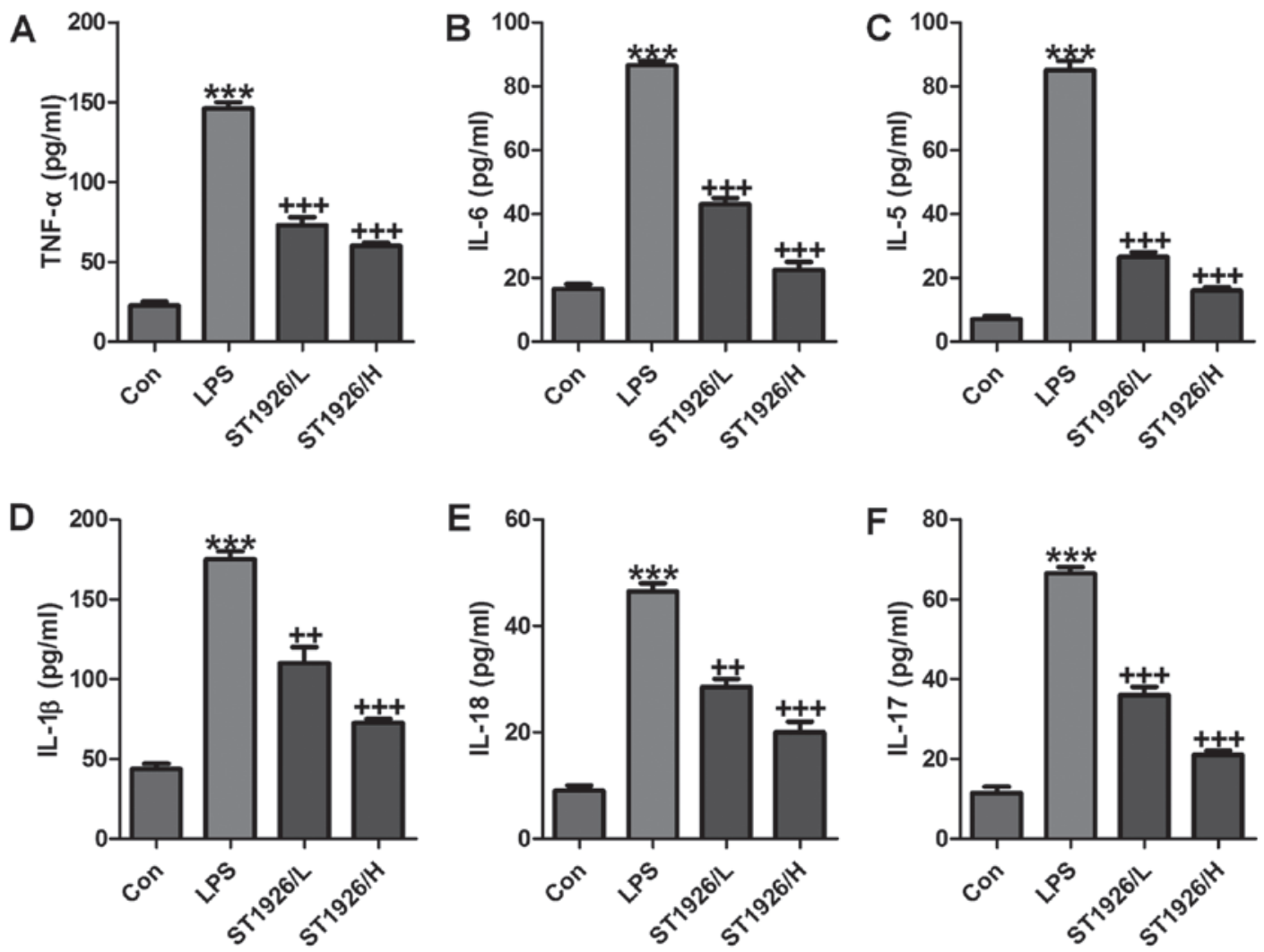

Figure 3. ST1926 improves pro-inflammatory cytokine releases caused by lipopolysaccharide (LPS). Serum pro-inflammatory cytokines were measured, including (A) tumor necrosis factor- $\alpha$ (TNF- $\alpha$ ), (B) interleukin-6 (IL-6), (C) IL-5, (D) IL-1 $\beta$, (E) IL-18 and (F) IL-17. The data are presented as mean \pm SD $(\mathrm{n}=8) .{ }^{*} \mathrm{p}<0.05$ and ${ }^{* *} \mathrm{p}<0.001$ vs. the control $(\mathrm{Con}) ;{ }^{+} \mathrm{p}<0.05,{ }^{++} \mathrm{p}<0.01$ and ${ }^{+++} \mathrm{p}<0.001 \mathrm{vs}$. LPS-induced mice (LPS). 
A
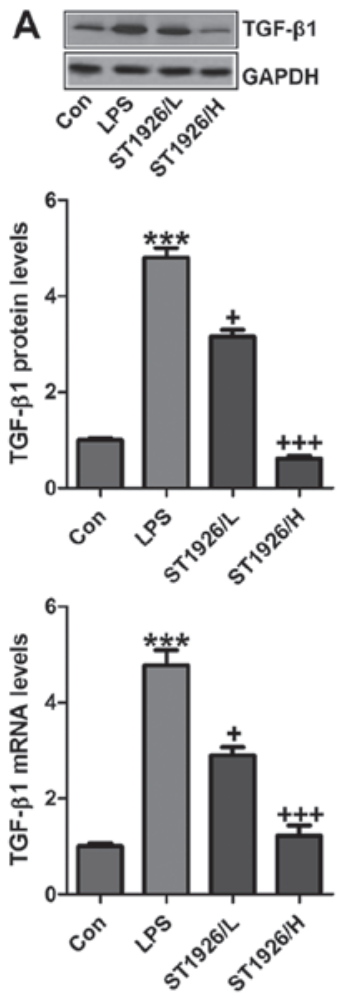

E
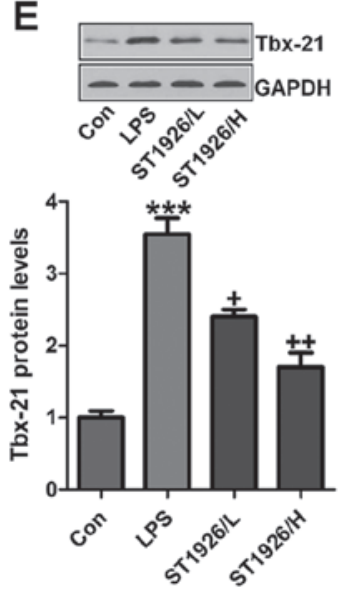

B
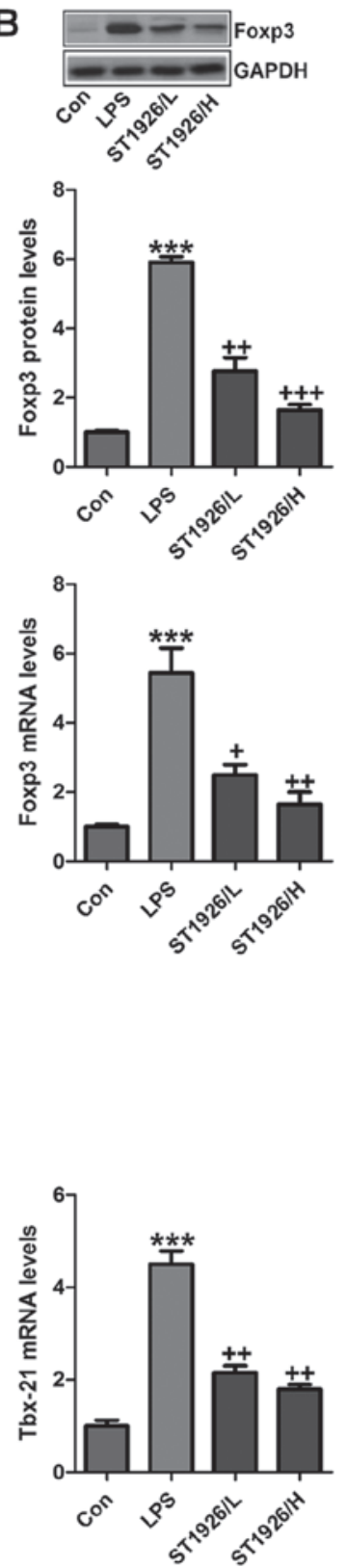

C
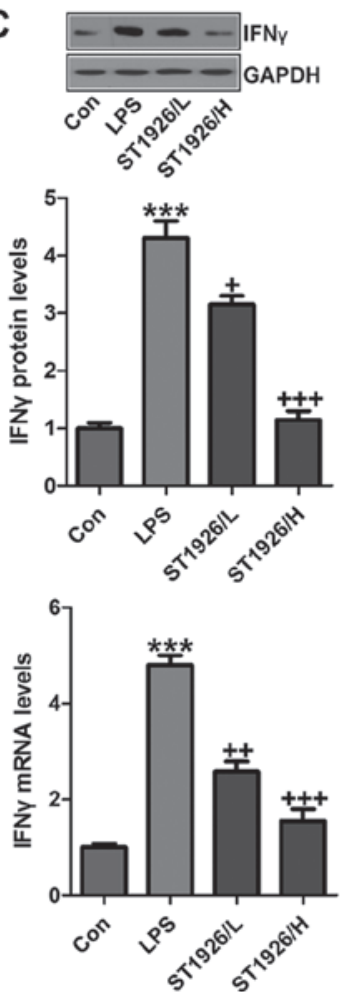

$\mathbf{F}$

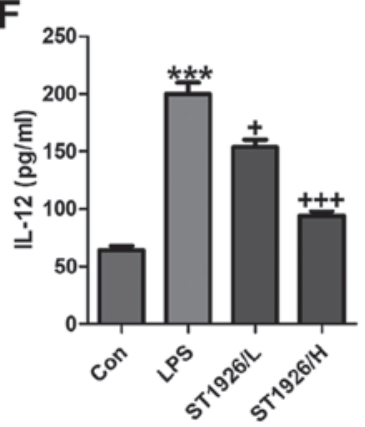

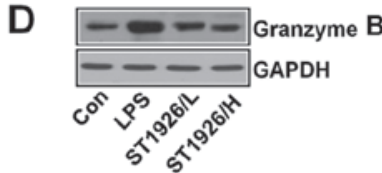
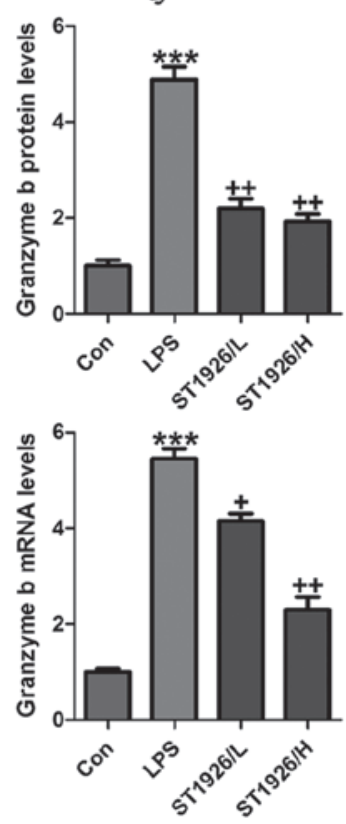

G

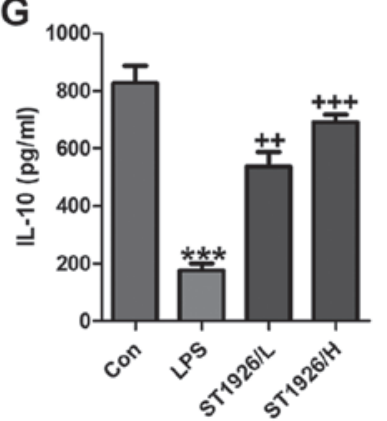

Figure 4. ST1926 suppresses inflammation response in lipopolysaccharide (LPS)-induced lung injury. Western blotting and RT-qPCR assays were used to calculate (A) TGF- $\beta 1$, (B) Foxp3, (C) IFN $\gamma$, (D) Granzyme B and (E) Tbx-21 protein and gene levels in LPS-treated lung tissue samples from mice in the presence or absence of ST1926. Serum levels of (F) interleukin-12 (IL-12) and (G) IL-10 were assessed. The data are presented as mean \pm SD ( $\mathrm{n}=8$ ). ${ }^{*} \mathrm{p}<0.05$ and ${ }^{* *} \mathrm{p}<0.001$ vs. the control (Con); ${ }^{+} \mathrm{p}<0.05,{ }^{++} \mathrm{p}<0.01$ and ${ }^{+++} \mathrm{p}<0.001$ vs. LPS-induced mice (LPS).

it. IL-10 secretion is the characteristic activity of cells in regulating inflammatory disease and a potent anti-inflammatory molecule, thereby suppressing the action of many pro-inflammatory and pro-fibrotic molecules. TBX21 is an important transcription factor of adaptive immunity (27-29). As shown in Fig. 4A, we found that TGF- $\beta 1$ was highly upregulated in LPS treatment, which was reduced due to ST1926 administration from the protein and gene levels, indicating the inflammatory cell accumulation. Foxp3, as another factor of $\mathrm{T}$ cell differentiation for lung injury regulation, was also found to be increased in LPS group. Notably, ST1926 significantly decreased its expression in a dose-dependent manner (Fig. 4B). INF $\gamma$ and GzmB are also reported to be highly expressed in acute lung injury (30). Similarly, INF $\gamma$, GzmB and Tbx21 protein and gene levels were apparently enhanced by LPS treatment, which were reduced by ST1926 administration through western blotting and RT-qPCR assays (Fig. 4C-E). In the end, IL-12 and IL-10 protein levels in serum of mice were calculated. IL-12, a proinflammatory cytokine, was upregulated by LPS. ST1926 showed suppressive role in IL-12 expression. In contrast, IL-10, as an important anti-inflammatory cytokine, was found to be reduced by LPS, which was reversed in ST1926 treatment (Fig. 4F and G). Taken together, the data above indicated that ST1926, at least partly had an inhibitory role in regulating inflammatory response.

ST1926-ameliorated inflammation response in mice induced by LPS is dependent on $N F-\kappa B$ signaling pathway. As mentioned above, inflammation response was observed. Thus, 

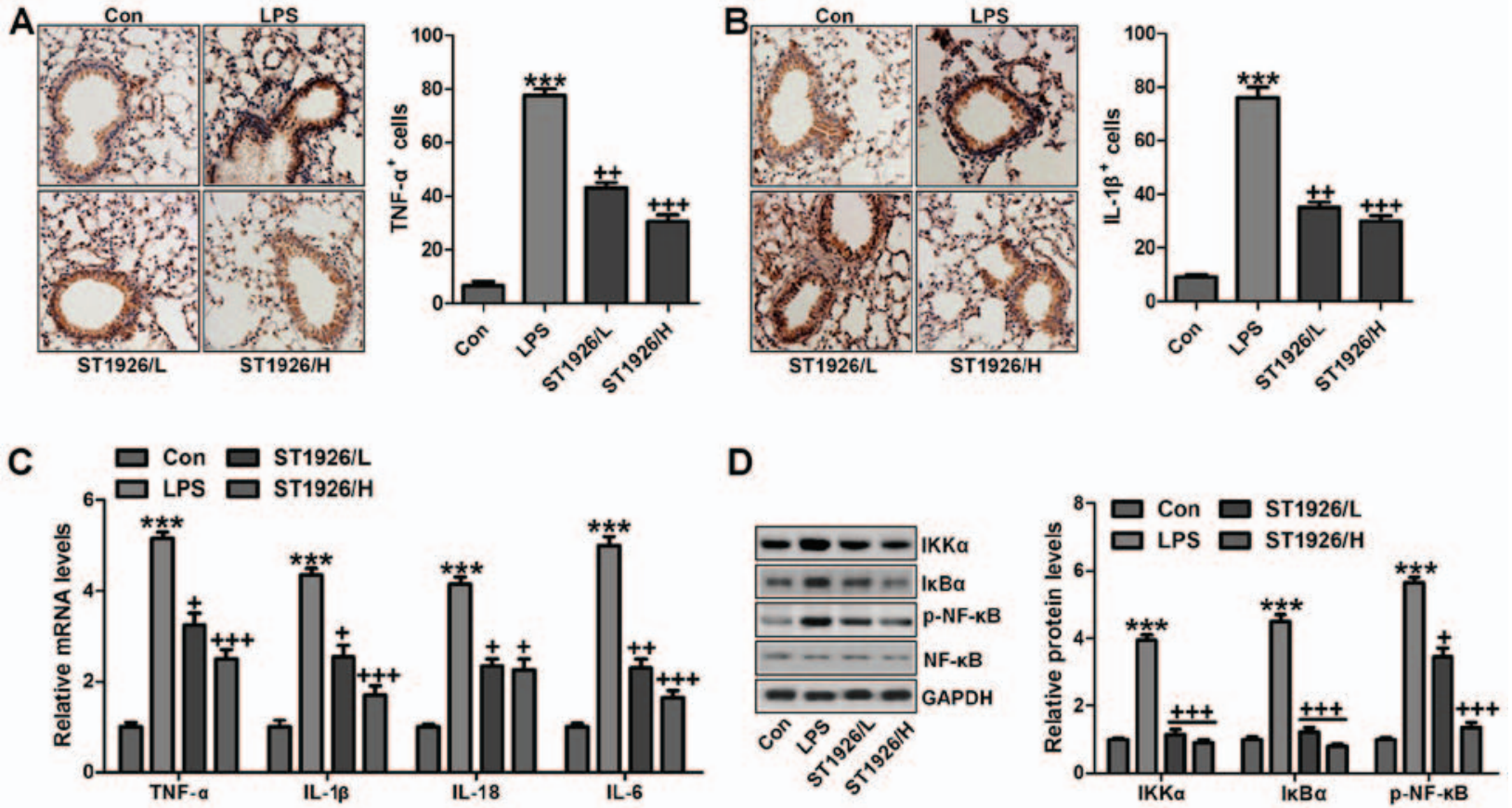

Figure 5. ST1926-ameliorates inflammation response in mice induced by lipopolysaccharide (LPS) is dependent on nuclear factor- $\kappa \mathrm{B}(\mathrm{NF}-\mathrm{\kappa B})$ signaling pathway. Immnohistochemical analysis of pro-inflammatory cytokines of (A) tumor necrosis factor- $\alpha$ (TNF- $\alpha$ ) and (B) interleukin-1 $\beta$ (IL-1 $\beta$ ) were assessed. (C) RT-qPCR assays were conducted to explore mRNA levels of TNF- $\alpha$, IL-1 $\beta$, IL-18 and IL-6. (D) Western blot assay was performed to investigate NF-kB

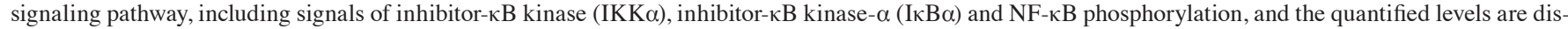
played. The data are presented as mean $\pm \mathrm{SD}(\mathrm{n}=8) .{ }^{*} \mathrm{p}<0.05$ and ${ }^{* *} \mathrm{p}<0.001$ vs. the control $(\mathrm{Con}) ;{ }^{+} \mathrm{p}<0.05,{ }^{++} \mathrm{p}<0.01$ and ${ }^{+++} \mathrm{p}<0.001$ vs. LPS-induced mice (LPS)

here we attempted to explore how ST1926 altered LPS-induced acute lung injury in mice. First, as shown in Fig. 5A and B, we further confirmed that pro-inflammatory cytokines of TNF- $\alpha$ and IL- $1 \beta$ were significantly stimulated through IHC analysis. ST1926 displayed attenuated role in controlling pro-inflammatory cytokine release. Furthermore, RT-qPCR analysis was carried out to confirm that ST1926 indeed suppressed LPS-caused inflammation response in the lung tissue of mice. As shown in Fig. 5C, TNF- $\alpha$, IL-18, IL-6 and IL-1 $\beta$ were enhanced for LPS treatment, which was reduced by ST1926 administration in a dose-dependent manner. NF- $\kappa \mathrm{B}$ signaling pathway is well known in modulating inflammatory response and controlling pro-inflammatory cytokine secretion, associated with IKK $\alpha$ and $\mathrm{I} \kappa \mathrm{B} \alpha$ activation (31). As shown in Fig. 5D, western blot analysis indicated that IKK $\alpha$ activation was significantly improved by LPS treatment, resulting in $\mathrm{I} \kappa \mathrm{B} \alpha$ expression and $\mathrm{NF}-\kappa \mathrm{B}$ phosphorylation eventually. Interestingly, ST1926 treatment could reverse $\mathrm{NF}-\kappa \mathrm{B}$ activation through inhibition of IKK $\alpha$ and I $\kappa \mathrm{B} \alpha$ expression, impeding inflammatory response. Taken together, ST1926 suppressed LPS-induced acute lung injury by inactivating NF- $\kappa \mathrm{B} / \mathrm{I} \kappa \mathrm{B} \alpha$.

ST1926 suppresses TLR4/MyD88 signal pathway to inactivate $N F-\kappa B$ activity. TLR4/MyD88 signaling pathway has been well explored in inflammation response through $\mathrm{NF}-\kappa \mathrm{B}$ signaling pathway regulation (32). Thus, here we attempted to explore if TLR4/MyD88 was involved in NF- $\kappa \mathrm{B}$ activation. As shown in Fig. 6A and B, TLR4 and MyD88 were found to be upregulated in LPS-treated group, which was in line with NF- $\mathrm{BB}$ alteration. ST1926 showed inhibitory role in TLR4 and MyD88 activation on protein levels. Furthermore, RT-qPCR analysis also indicated that LPS induced high gene expression of TLR4 and MyD88, and reversed TLR4 and MtD88 gene levels were observed (Fig. 6C). Immunofluorescent assay was performed to evidence that TLR4 was activated in LPS-treated group, which was reduced for ST1926 administration (Fig. 6D). The data indicated that ST1926 attenuated inflammation response induced by LPS relying on TLR4 signaling pathway suppression.

ST1926 impeded oxidative stress in mice with acute lung injury induced by LPS. Oxidative stress is a leading cause in various diseases, including a variety of cancers, and acute liver and renal injury (33). Also, in acute lung injury oxidative stress was also reported (34). Thus, we proposed that ST1926 may perform its role in LPS-induced acute lung injury by inhibiting ROS generation. In order to prove our hypothesis, first in serum and lung tissue samples, SOD and CAT activity was investigated after LPS treatment, activity of SOD and CAT was highly reduced, while MDA was discovered with higher levels in LPS-treated group both in serum and in lung tissue samples (Fig. 7A and B). However, ST1926 administration significantly upregulated SOD and CAT activity, while the MDA levels were reduced. In addition, oxidants of $\mathrm{O}_{2}{ }^{-}$and $\mathrm{H}_{2} \mathrm{O}_{2}$ as well as nitrate levels in the LPS-induced lung tissue samples were found to be higher than that in the control group (Fig. 7C). Also, ST1926 showed inhibitory role in expression of these oxidants, which may be another property of ST1926 to attenuate LPS-induced acute lung injury.

In addition, NOx, iNOS and MPO levels were assessed to indicate the extent of lung injury. As shown in Fig. 8A, LPS enhanced NO levels in the tissue samples, which could be reversed by ST1926 administration. Using MPO 


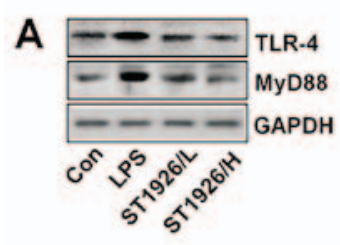

B
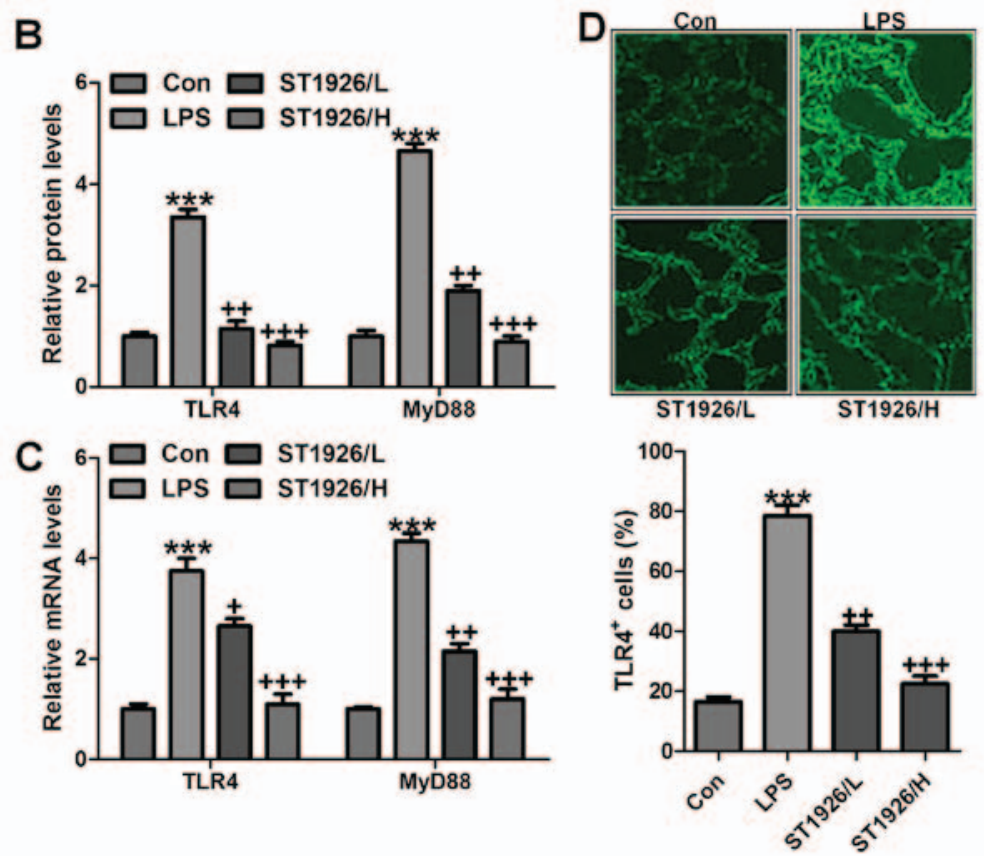

Figure 6. ST1926 suppresses Toll-like receptor 4 (TLR4)/MyD88 signal pathway to inactivate nuclear factor-kB (NF-kB) activity. (A) TLR4 and MyD88 protein levels were evaluated through western blot analysis. (B) The quantification of TLR4 and MyD88 is shown following immunoblotting analysis. (C) RT-qPCR was used to determine TLR4 and MyD88 gene levels. (D) Immunofluorescence was included to further test TLR4 expression levels. The data are presented as mean $\pm \mathrm{SD}(\mathrm{n}=8) .{ }^{*} \mathrm{p}<0.05$ and ${ }^{* *} \mathrm{p}<0.001$ vs. the control (Con); ${ }^{+} \mathrm{p}<0.05,{ }^{++} \mathrm{p}<0.01$ and ${ }^{+++} \mathrm{p}<0.001$ vs. lipopolysaccharide (LPS)-induced mice (LPS).

A

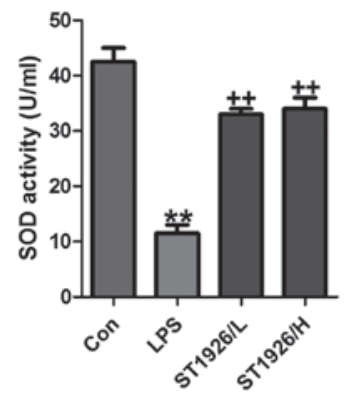

B
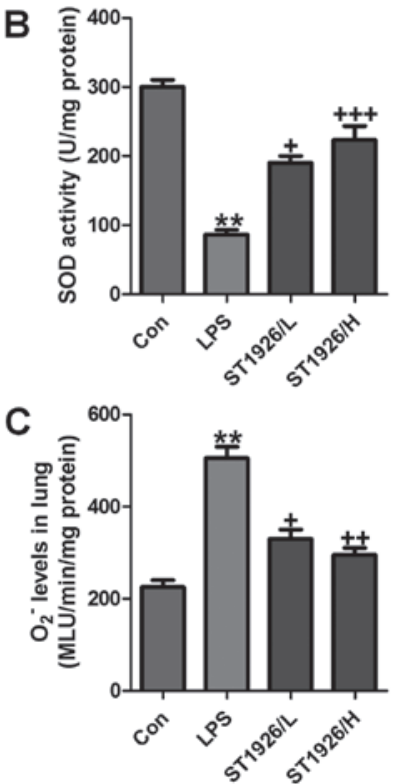
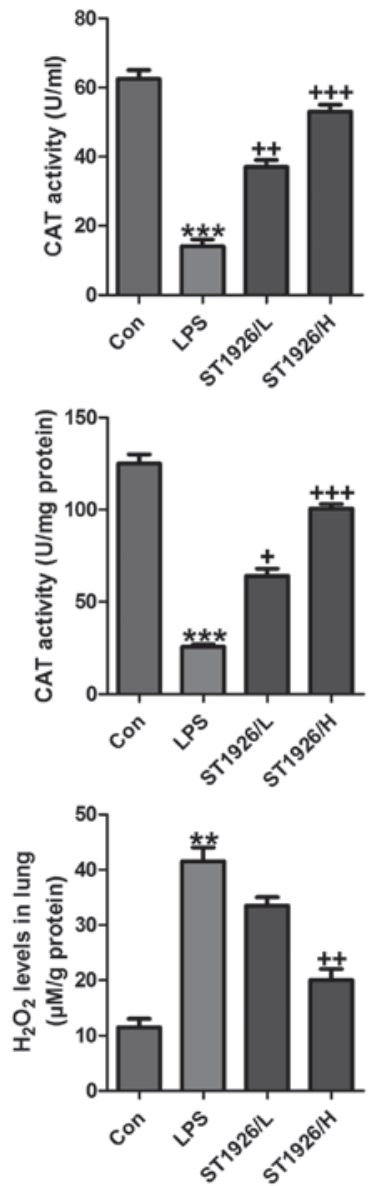
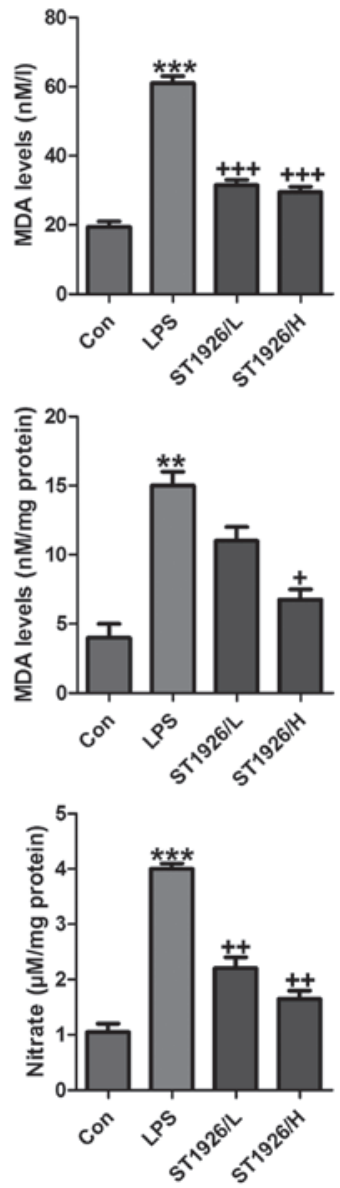

Figure 7. ST1926 impedes oxidative stress in mice with acute lung injury induced by lipopolysaccharide (LPS). (A) SOD activity, CAT activity and MDA levels were measured in the serum of mice after LPS induction in the absence or presence of ST1926 at different doses. (B) SOD activity, CAT activity and MDA levels were measured in the lung tissue samples of mice after LPS induction in the absence or presence of ST1926 at different doses. (C) $\mathrm{O}_{2}{ }^{-}$and $\mathrm{H}_{2} \mathrm{O}_{2}$, as well as nitrate levels in the LPS-induced lung tissue samples were measured. The data are presented as mean \pm SD $(n=8)$. " $p<0.05$ and ${ }^{* *} p<0.001$ vs. the control (Con); ${ }^{+} \mathrm{p}<0.05,{ }^{++} \mathrm{p}<0.01$ and ${ }^{+++} \mathrm{p}<0.001$ vs. LPS-induced mice (LPS). 

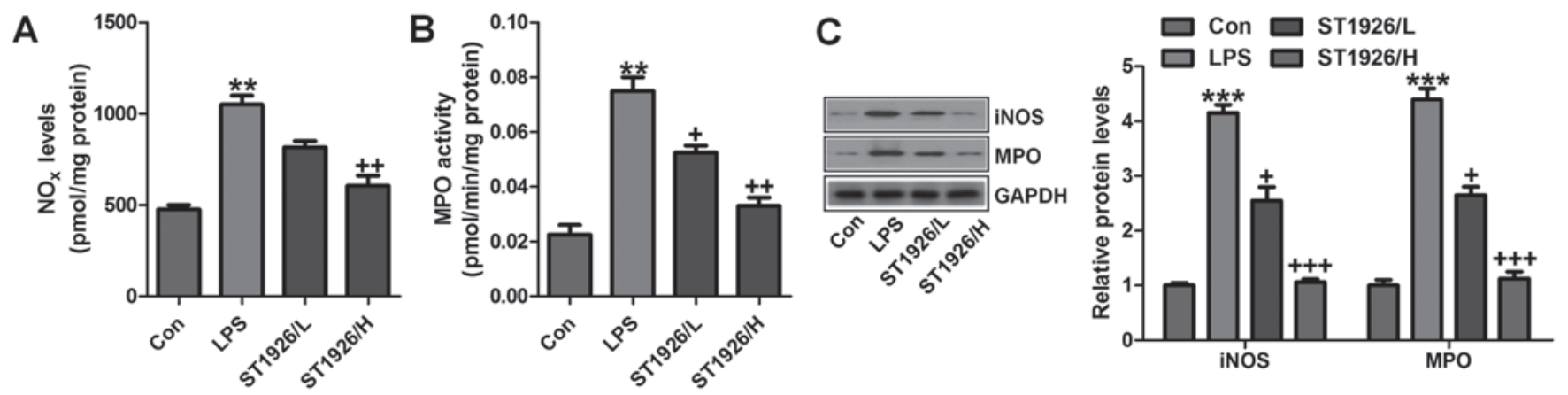

Figure 8. ST1926 reduced reactive oxygen species (ROS) generation from iNOS/MPO inhibition. (A) NOx levels in the lung tissue samples were examined. (B) MPO activity was measured in the lung tissue specimens obtained from mice pre-treated with lipopolysaccharide (LPS) and/or ST1926 under different conditions. (C) The representative images of iNOS and MPO assessed by western blot analysis and the quantification was shown. The data are represented as mean $\pm \operatorname{SD}(n=8) .{ }^{*} \mathrm{p}<0.05$ and ${ }^{* *} \mathrm{p}<0.001$ vs. the control $(\mathrm{Con}) ;{ }^{+} \mathrm{p}<0.05,{ }^{++} \mathrm{p}<0.01$ and ${ }^{+++} \mathrm{p}<0.001$ vs. LPS-induced mice (LPS).
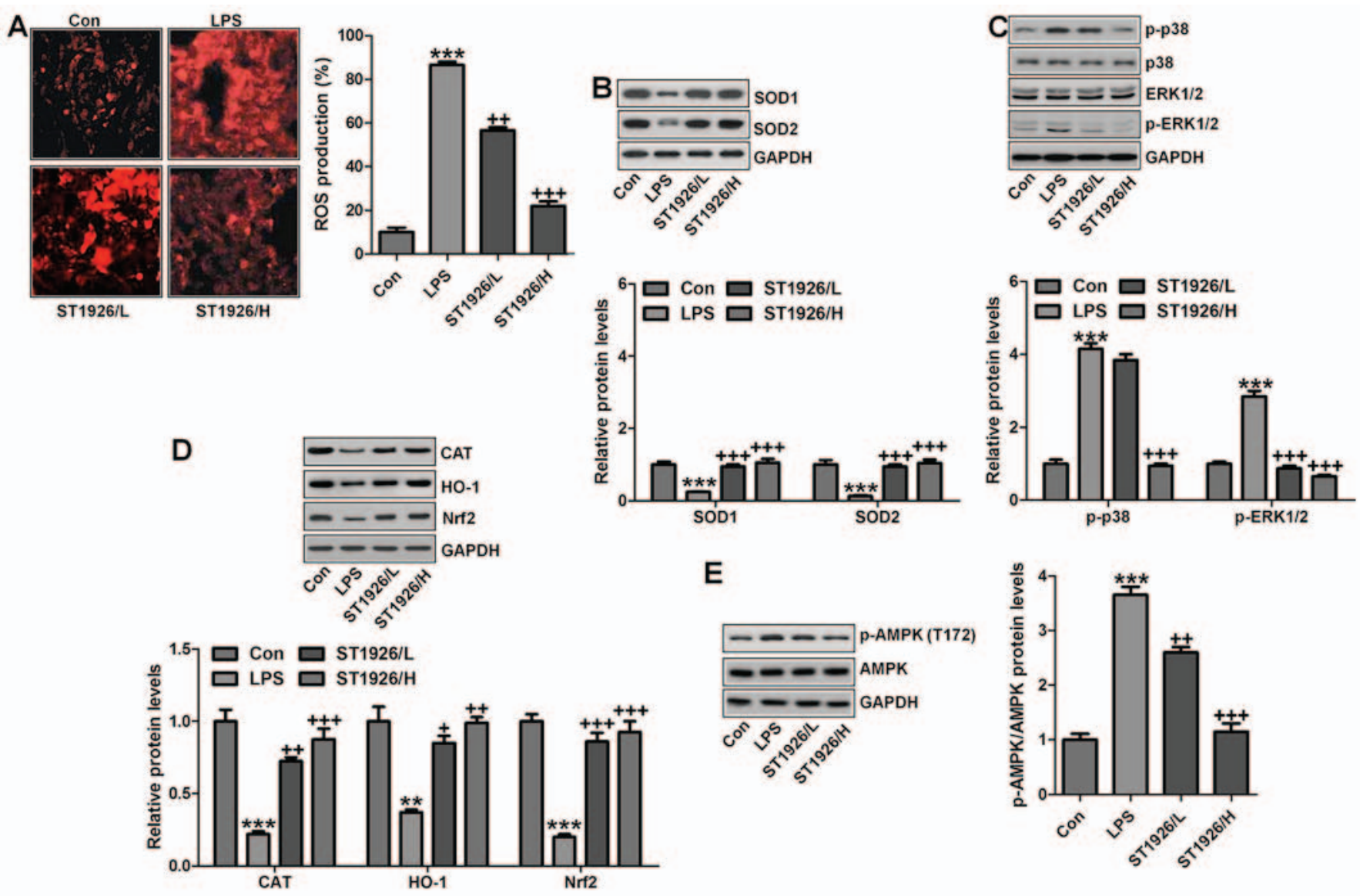

Figure 9. AMPK/p38/extracellular receptor kinase 1/2 (ERK1/2) signaling pathway was inhibited by ST1926 administration in lipopolysaccharide (LPS)-induced mice. (A) Images of reactive oxygen species (ROS) production are shown, and the quantified levels of ROS generation are displayed. (B) SOD1 and SOD2 protein levels were calculated through western blot assay. The quantification of SOD1 and SOD2 is shown. (C) p38/ERK1/2 signaling pathway was investigated by immunoblotting, and the phosphorylated p38 and ERK1/2 protein levels were quantified. (D) Western blot analysis was used to calculate CAT, haeme oxygenase-1 (HO-1) and Nrf2 protein levels, and the quantification of these molecules are shown. (E) Phosphorylated AMPK at T172 was analyzed by western blot assays. The data are presented as mean $\pm \mathrm{SD}(\mathrm{n}=8) .{ }^{*} \mathrm{p}<0.05$ and ${ }^{* *} \mathrm{p}<0.001 \mathrm{vs}$. the control (Con); ${ }^{+} \mathrm{p}<0.05,{ }^{++} \mathrm{p}<0.01$ and ${ }^{+++} \mathrm{p}<0.001$ vs. LPS-induced mice (LPS).

activity, we found that LPS induced neutrophil infiltration in the lungs of LPS-treated mice, and ST1926 reduced MPO activity (Fig. 8B). MPO activity in pulmonary parenchyma, reflecting the activation of neutrophils, was largely upregulated in acute lung injury condition. NO is produced by the oxidation of 1-arginine (1-arg) to l-citrulline and $\mathrm{NO}$, which is catalyzed by NOS. Thus, iNOS is generally considered to be the major contributor to the pathogenesis of acute lung injury (35). In our study, we found that iNOS protein expression levels were highly induced for LPS treatment, which were reversed by ST1926 administration (Fig. 8C). Further, protein levels of MPO, in line with the data above, were promoted in LPS-treated group. The expression levels were downregulated for ST1926 through western blot analysis (Fig. 8C). The data 

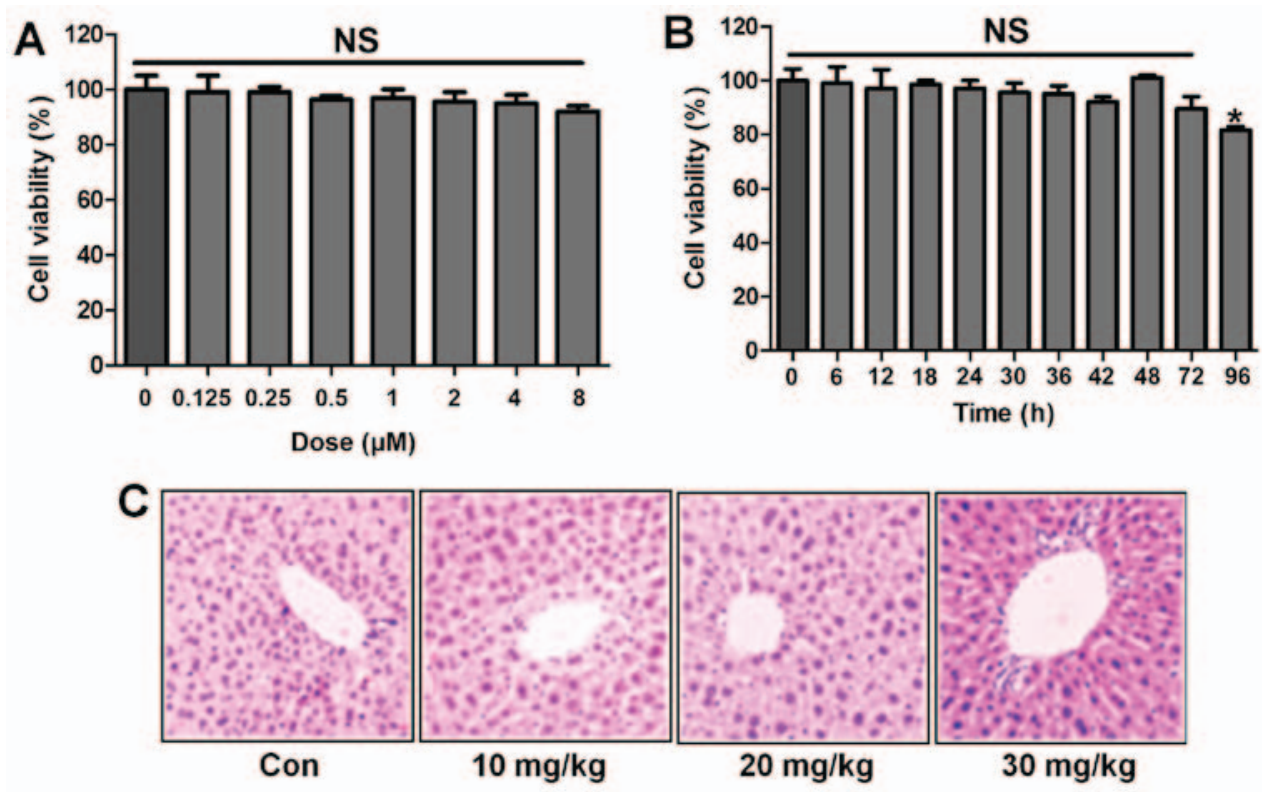

Figure 10. ST1926 shows no toxicity in vitro and in vivo. (A) MTT analysis was included to explore the lung epithelia cell viability with different concentrations of ST1926 for $24 \mathrm{~h}$. (B) ST1926 (8 $\mu \mathrm{M})$ was administered to lung epithelial cells for different times to determine cell viability. (C) Hematoxylin and eosin (H\&E) staining analysis of mouse liver without lipopolysaccharide (LPS) and ST1926 administration. The data are presented as mean \pm SD (n=8). ${ }^{*} p<0.05$ and ${ }^{* *} \mathrm{p}<0.001$ vs. the control (Con); ${ }^{+} \mathrm{p}<0.05,{ }^{++} \mathrm{p}<0.01$ and ${ }^{+++} \mathrm{p}<0.001$ vs. LPS-induced mice (LPS).

above further indicated that LPS induced acute lung injury due to NOx, MPO and iNOS acceleration, which was in line with previous studies $(36,37)$. ST1926, at least partly, could ameliorate LPS-induced acute lung injury by downregulating the activity of these factors.

p38/ERK1/2 signaling pathway is inhibited by ST1926 administration in LPS-induced mice. The data above indicated that ST1926 suppressed oxidants levels, which is related to upregulated anti-oxidants to improve lung injury. Thus, here we attempted to further explore the possible molecular mechanism regarding ROS. As shown in Fig. 9A, ROS production was highly elevated in LPS-treated group, which was reversed by ST1926 administration. Consistently, anti-oxidants of SOD1 and SOD2 were also upregulated by ST1926 treatment in LPS-induced mice with acute lung injury (Fig. 9B). Finally, p38 and ERK1/2 signaling pathway was investigated to explore whether they were involved in ROS production, mediated by ST1926 in LPS-treated lung tissue samples. As reported previously, p38 and ERK1/2 are of great importance in ROS generation (38). Similarly, in our study, we found that phosphorylated p38 and ERK1/2 were markedly enhanced by LPS treatment, which was reduced by ST1926 administration (Fig. 9C). The data above indicated that ST1926 could reduce ROS production, which was related to p38/ERK1/2 signaling pathway inactivation.

Moreover, this study indicated that in the LPS-induced lung injury, CAT, HO-1 and Nrf2 levels were downregulated in LPS treatment. In contrast, $\mathrm{O}_{2}^{-}$and $\mathrm{H}_{2} \mathrm{O}_{2}$ were upregulated. Of note, ST1926 suppressed ROS production by enhancing anti-oxidant expression while reducing oxidants (Fig. 9D). AMP-activated protein kinase (AMPK) is a serine/threonine protein kinase that serves as an energy sensor in the regulation of cellular metabolism. Additionally, AMPK is reported to be closely associated with ROS production (39). Here, in our study, we found that AMPK phosphorylated levels were significantly reduced for LPS, and ST1926 augmented AMPK phosphorylation of Thr172, indicating that AMPK phosphorylation induced by ST1926 may be a key point to modulate ROS generation (Fig. 9E).

ST1926 shows no toxicity in vitro and in vivo. Following the results above, we attempted to explore if ST1926 was effective in LPS-induced acute lung injury in vitro by the use of lung epithelial cells. As shown in Fig. 10A, the results indicated that with the increasing of ST1926, even at the highest level, no significant difference was observed on cells. In Fig. 10B, the cell viability showed no significant difference at $8 \mu \mathrm{M}$ ST1926 treatment for different times until $72 \mathrm{~h}$. In addition, H\&E staining suggested that ST1926 at different concentrations exhibited no toxic role in the liver of mice without LPS treatments (Fig. 10C). The data above indicated that ST1926 could ameliorate acute lung injury without any toxicity.

ST1926 suppresses inflammation response and ROS production in lung epithelia cells in vitro. We confirmed that ST1926 showed no toxicity in cells in vitro. Thus, here, we attempted to explore if ST1926 could perform its role in vitro. As shown in Fig. $11 \mathrm{~A}, \mathrm{p}-\mathrm{NF}-\kappa \mathrm{B}$ was found to be upregulated in LPS-induced lung epithelial cells through immunofluorescence. ST1926 at 4 and $8 \mu \mathrm{M}$ significantly reduced NF- $\mathrm{KB}$ phosphorylated levels. In line with the results in vivo, pro-inflammatory cytokines of TNF- $\alpha$, IL-1 $1 \beta$, IL-18 and IL-6 were apparently upregulated for LPS induction and ST1926 downregulated the inflammatory cytokine release induced by LPS (Fig. 11B). TLR4/MyD88 and IKK $\alpha / \mathrm{I} \kappa \mathrm{B} \alpha$ signaling pathways were activated by LPS induction, which were inactivated by ST1926 administration (Fig. 11C and D). Additionally, LPS-induced ROS production was decreased in ST1926-treated groups, accompanied by high level of SOD1 

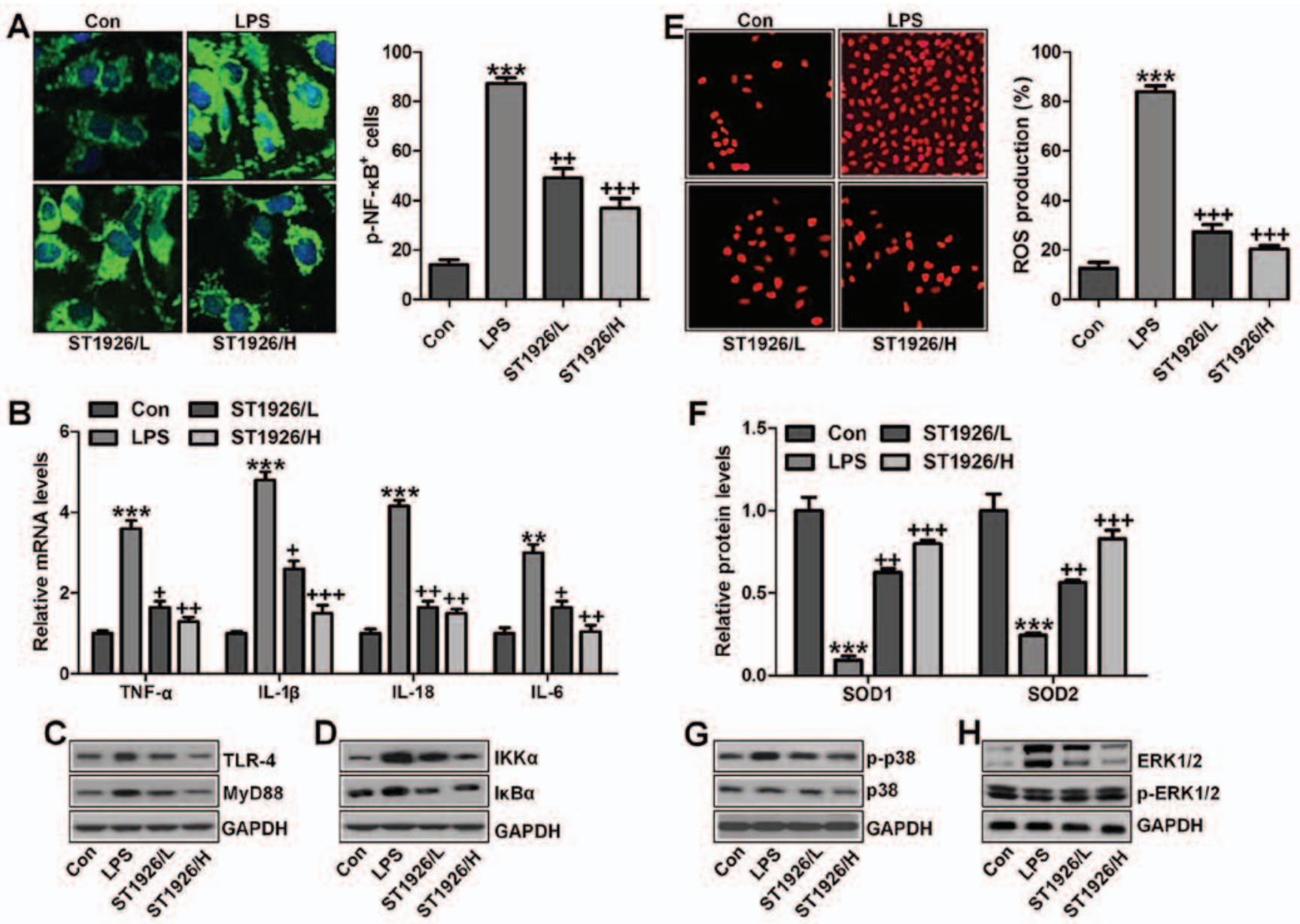

ST1926/L

\section{$\mathbf{F}$}
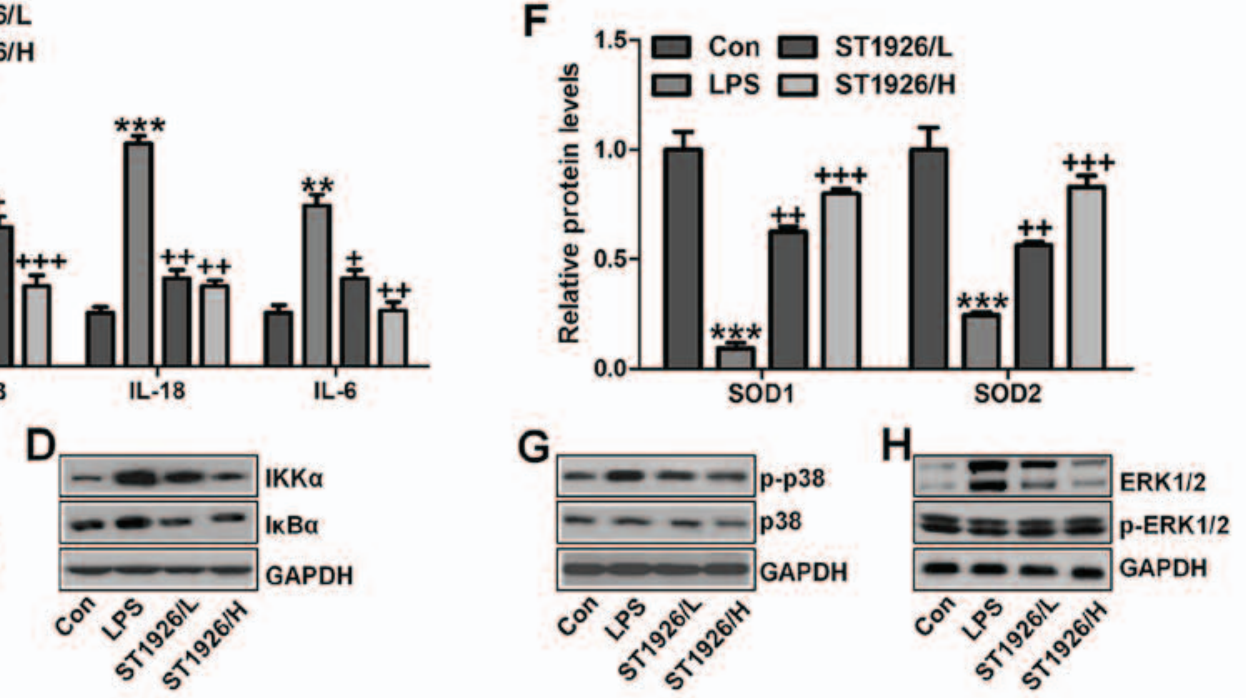

I
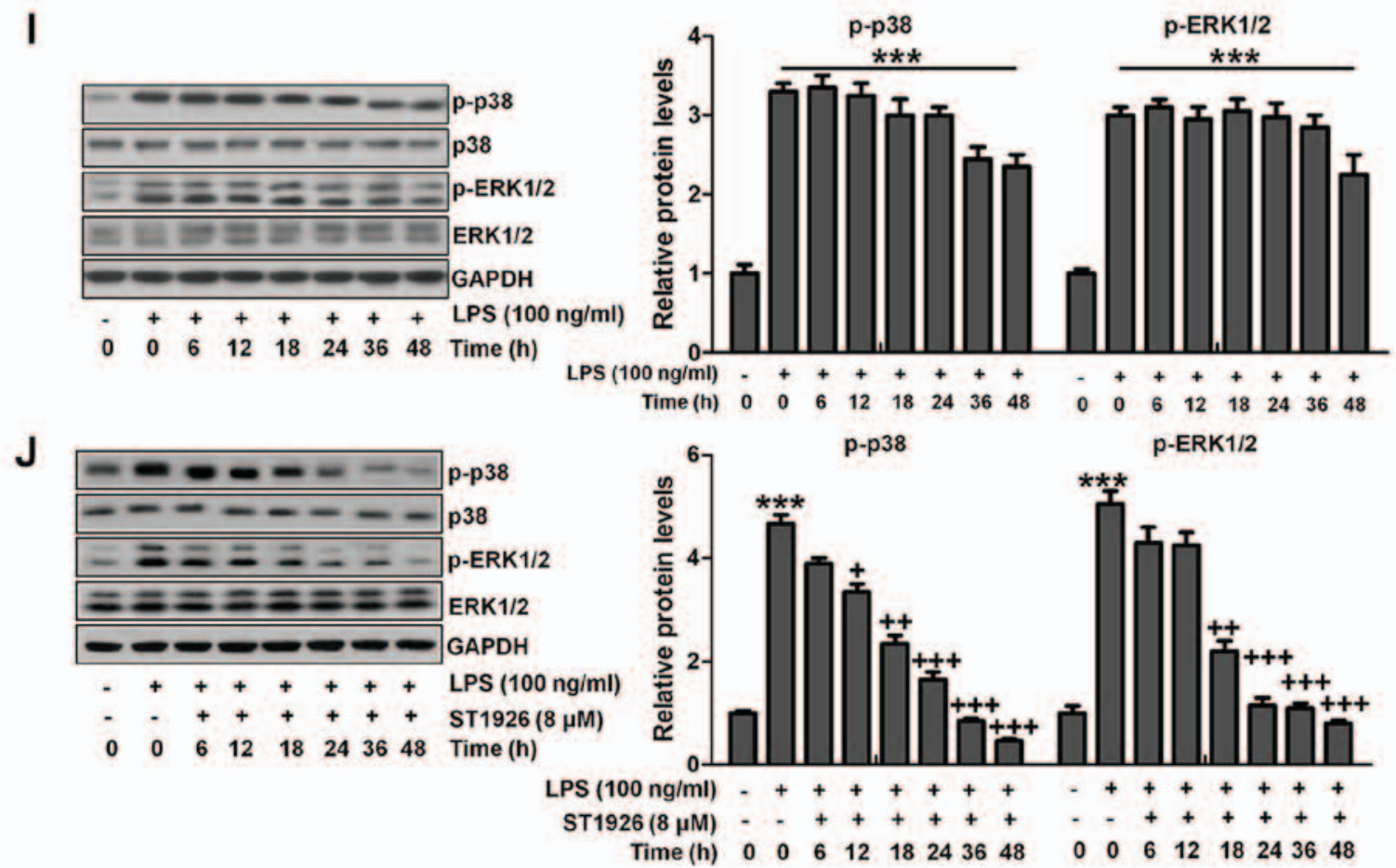

Figure 11. ST1926 suppresses inflammation response and reactive oxygen species (ROS) production in lung epithelia cells in vitro. (A) Immunofluorescence of phosphorylated nuclear factor- $\kappa \mathrm{B}$ (NF-kB) was evaluated. (B) Tumor necrosis factor- $\alpha$ (TNF- $\alpha$ ), interleukin-1 $\beta$ (IL-1 $\beta$ ), IL-18 and IL-6 mRNA levels were calculated via RT-qPCR analysis. (C) Western blot analysis was used determine Toll-like receptor 4 (TLR4) and MyD88 expression levels in lipopolysaccha-

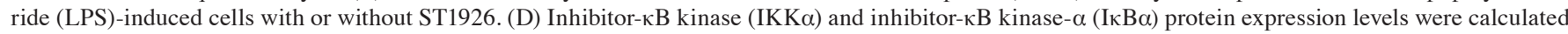
through western blot analysis. (E) ROS levels were calculated in different groups of cells. (F) SOD1 and SOD2 mRNA levels were determined via RT-qPCR analysis. (G) Phosphorylated p38, and (H) extracellular receptor kinase 1/2 (ERK1/2) was determined by the use of western blot analysis. (I) MLE-12 cells were treated with $100 \mathrm{ng} / \mathrm{ml}$ LPS for different times as indicated. Then, western blot analysis was conducted to investigate p38 and ERK1/2 phosphorylation. (J) ST1926 reduced p38 and ERK1/2 phosphorylation in MLE-12 cells after LPS treatment in the presence or absence of ST1926 for different times from 0 to $48 \mathrm{~h}$. Western blot assays were used to explore $\mathrm{p} 38$ and ERK1/2 activation. 

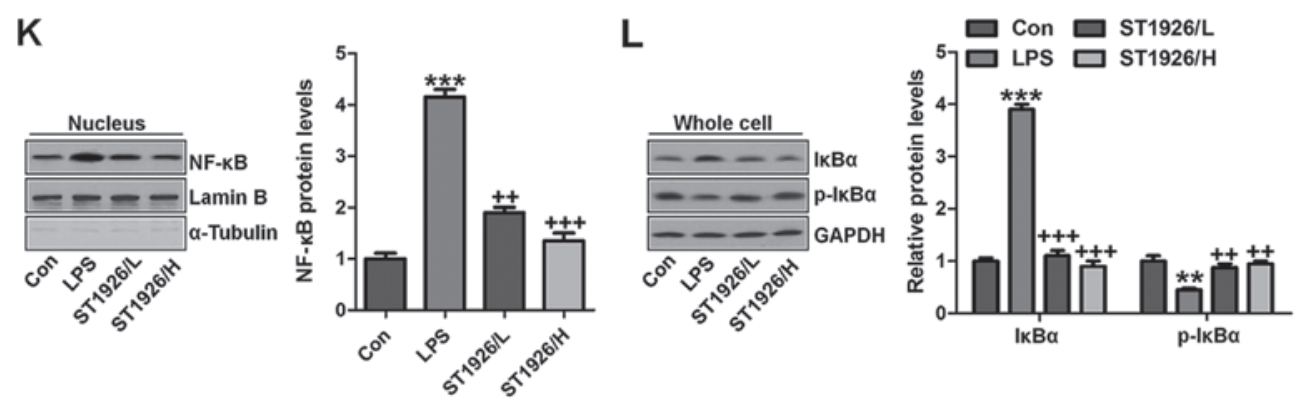

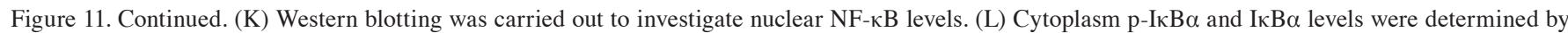
western blot analysis. The ratio of $\mathrm{p}-\mathrm{I} \kappa \mathrm{B} \alpha$ to $\mathrm{I \kappa B} \alpha$ was exhibited. The data are represented as mean $\pm \mathrm{SD}(\mathrm{n}=8)$. " $\mathrm{p}<0.05$ and ${ }^{* *} \mathrm{p}<0.001 \mathrm{vs}$. the control (Con); ${ }^{+} \mathrm{p}<0.05,{ }^{++} \mathrm{p}<0.01$ and ${ }^{+++} \mathrm{p}<0.001$ vs. LPS-induced mice (LPS).
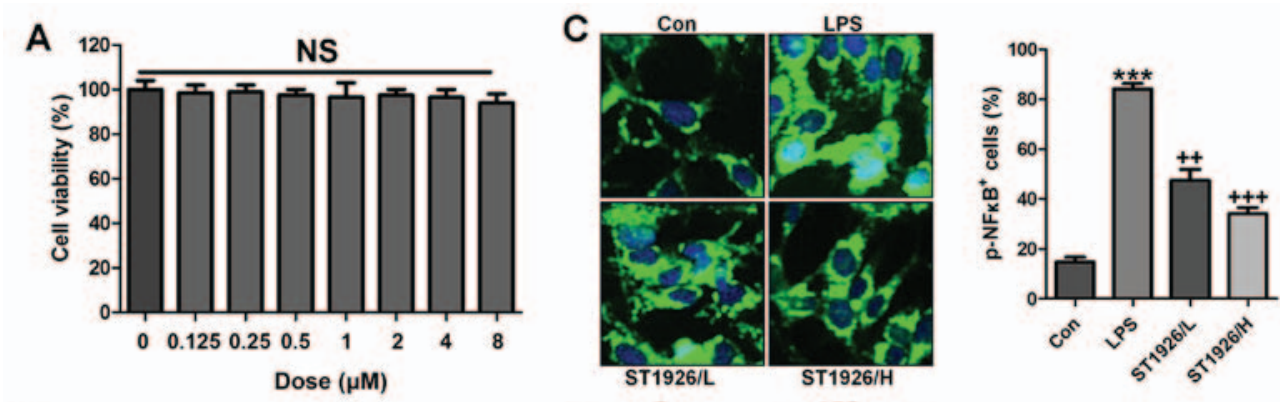

B
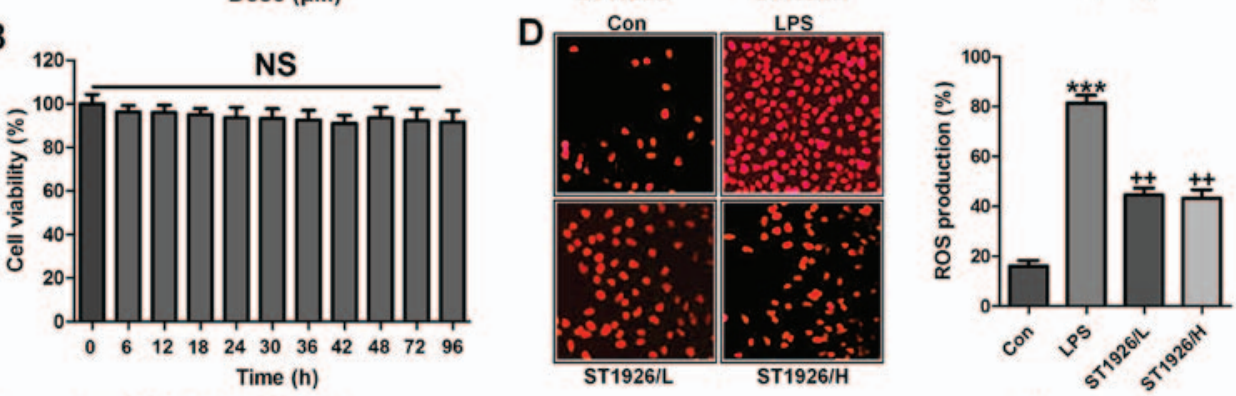

$\mathbf{E}$

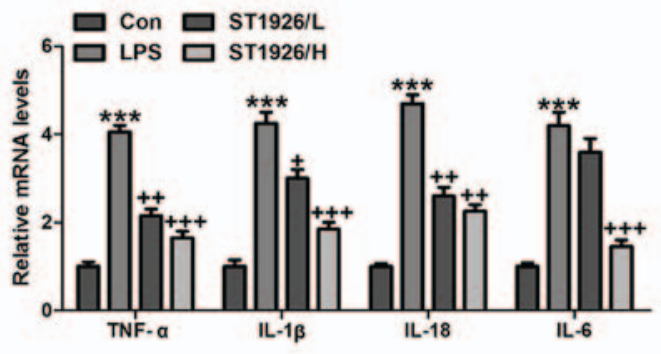

G
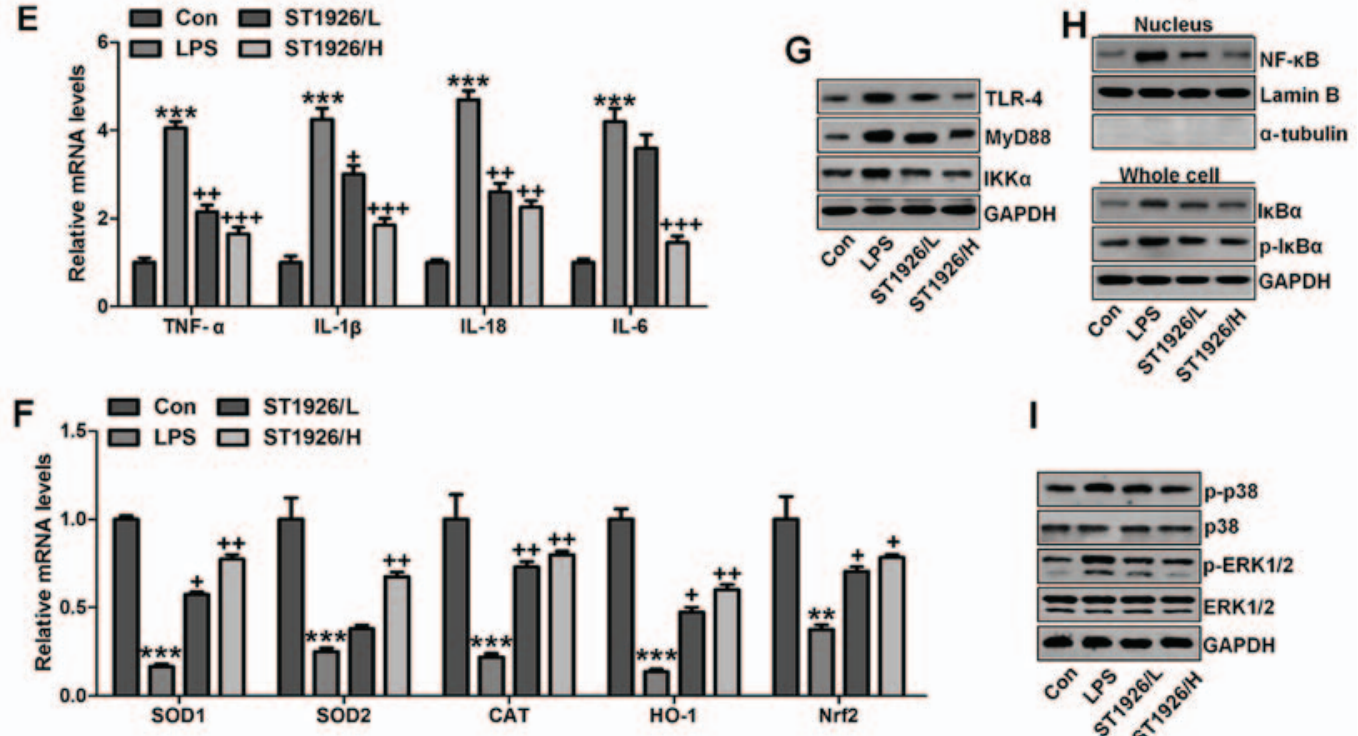

I

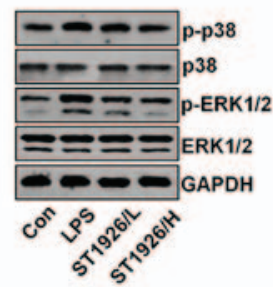

Figure 12. ST1926 inhibits inflammation response and reactive oxygen species (ROS) generation in human bronchial epithelial cells. (A) Human bronchial epithelial cells were treated with different concentrations of ST1926 at different concentrations for $24 \mathrm{~h}$. Then, the cell viability was calculated through MTT analysis. (B) Human bronchial epithelial cells were treated with $8 \mu \mathrm{M} \mathrm{ST1926}$ for different time, followed by MTT assays. (C) The phosphorylated nuclear factor- $\mathrm{\kappa B}$ (NF-kB) levels were measured by immunofluorescent analysis. (D) ROS generation was evaluated and the quantification was displayed. (E) RT-qPCR assays were performed to determine tumor necrosis factor- $\alpha$ (TNF- $\alpha$ ), interleukin-1 $\beta$ (IL-1 $\beta$ ), IL-18 and IL- 6 gene levels in cells under different treatment. (F) SOD1, SOD2, CAT, haeme oxygenase-1 (HO-1) and Nrf2 mRNA levels were calculated through RT-qPCR assays. (G) Toll-like receptor 4 (TLR4), MyD88 and inhibitor- $\mathrm{\kappa B}$ kinase $(\mathrm{IKK} \alpha)$ protein expression levels were measured by western blot analysis. (H) Western blotting was carried out to investigate nuclear

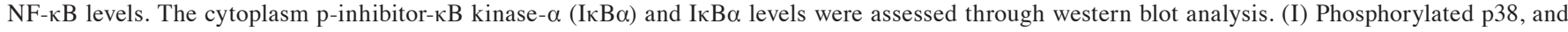
(H) extracellular receptor kinase 1/2 (ERK1/2) was determined by western blot analysis. 

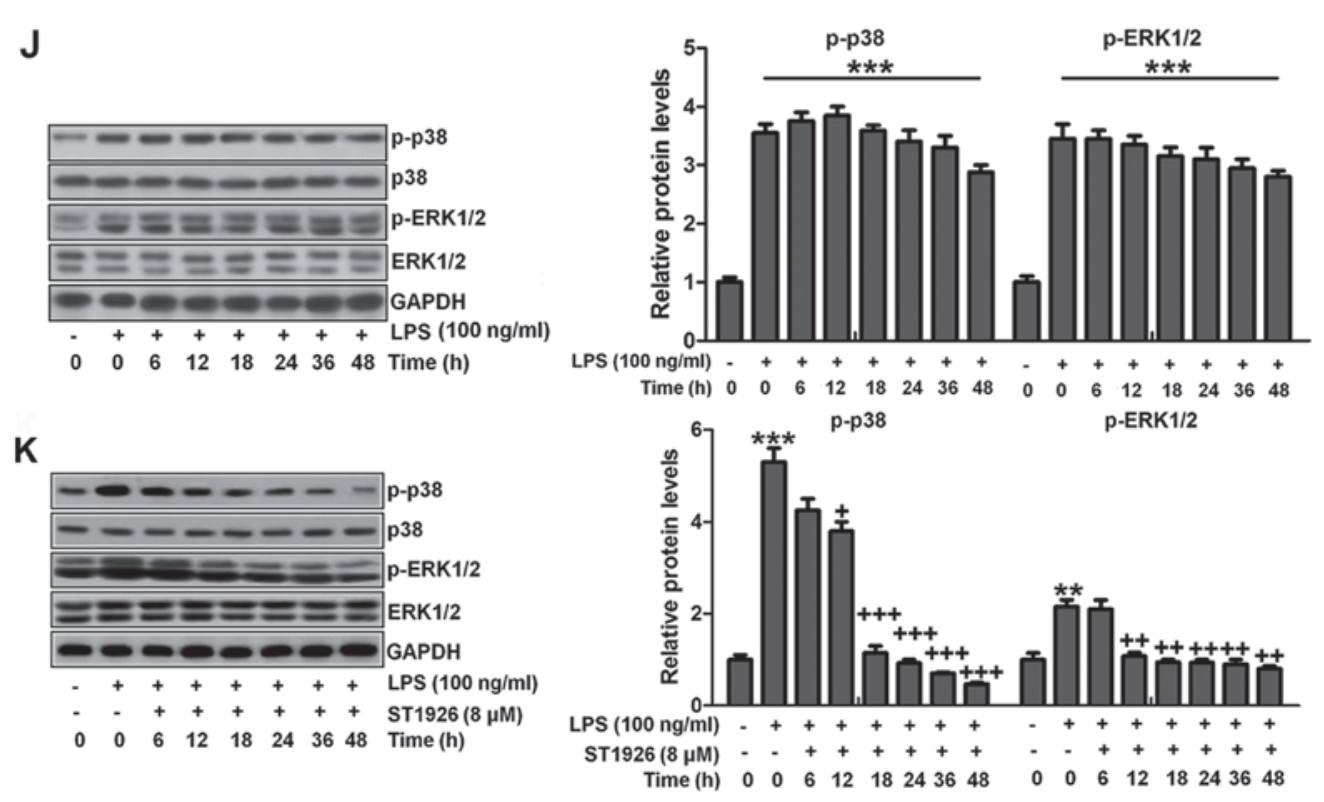

Figure 12. Continued. (J) NHBE cells were exposed to $100 \mathrm{ng} / \mathrm{ml}$ lipopolysaccharide (LPS) for different times as indicated, followed by western blot analysis. (K) ST1926 reduced p38 and ERK1/2 phosphorylation in human bronchial epithelial cells after LPS treatment with or without ST1926 administration from 0 to $48 \mathrm{~h}$. Then, western blot assays were used to explore $\mathrm{p} 38$ and ERK1/2 activation. The data are presented as mean \pm SD (n=8). ${ }^{*} \mathrm{p}<0.05$ and ${ }^{* *} \mathrm{p}<0.001 \mathrm{vs.} \mathrm{the}$ control (Con); ${ }^{+} \mathrm{p}<0.05,{ }^{++} \mathrm{p}<0.01$ and ${ }^{+++} \mathrm{p}<0.001$ vs. LPS-induced mice (LPS).

and SOD2 (Fig. 11E and F). Further, phosphorylated p38 and ERK1/2 improved by LPS treatment. Significantly, ST1926 administration could inactivate p38 and ERK1/2 activity, ameliorating ROS production (Fig. 11G and H). Following, the cells were exposed to $100 \mathrm{ng} / \mathrm{ml}$ LPS for different times, ranging from 0 to $48 \mathrm{~h}$. Next, western blot analysis was used to calculate p38 and ERK1/2 phosphorylation. As shown in Fig. 11I, we found that LPS treatment activated p38 and ERK1/2 levels, and with the increase in treatment time, the phosphorylated form was sustained until $48 \mathrm{~h}$, indicating that ROS may be activated by LPS exposure. As shown in Fig. 11J, we found that LPS significantly upregulated p38 and ERK1/2 phosphorylation, which were reduced for ST1926 in a timedependent manner. After ST1926 treatment for 12 and $18 \mathrm{~h}$, significant difference was observed in p38 and ERK1/2 activation, respectively. Furthermore, as shown in Fig. 11K, the NF- $\mathrm{KB}$ levels in the nucleus were found to be upregulated for LPS treatment, which was in line with p-NF- $\mathrm{BB}$ alteration in cytoplasm to enhance pro-inflammatory transcription, contributing to pro-inflammatory cytokines secretion. Of note, ST1926 showed significant role in reducing NF- $\mathrm{KB}$ in the nucleus, subsequently downregulating pro-inflammatory cytokine release. In addition, the whole cell IкB $\alpha$ levels were upregulated due to LPS treatment, while $\mathrm{p}-\mathrm{I} \kappa \mathrm{B} \alpha$ was down-

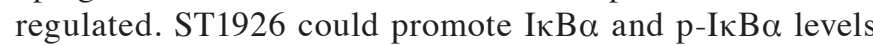
considerably (Fig. 11L). Thus, we supposed that ST1926 could ameliorate inflammation response by reducing NF- $\mathrm{KB}$ translocation into the nucleus. The above data indicated that ST1926 indeed attenuated LPS-induced lung injury in vitro via inhibiting inflammation and ROS production.

ST1926 inhibits inflammation response and ROS generation in human bronchial epithelial cells. In this regard, normal human bronchial epithelial cells (NHBE) were included to further explore how ST1926 regulated LPS-induced damage in lung cells. As shown in Fig. 12A, cell viability was investigated with increasing concentrations of ST1926, no significant difference was observed among various groups. Further, $8 \mu \mathrm{M}$ ST1926 was administered to cells for different times as indicated, ranging from 0 to $90 \mathrm{~h}$. Then, MTT analysis was carried out to investigate the cell viability, which showed no significant change among different groups (Fig. 12B). Inflammatory response and ROS have been revealed to be induced by LPS. The phosphorylated NF- $\kappa B$ and ROS generation was dramatically upregulated by LPS induction (Fig. 12C and D), which were downregulated in ST1926-treated groups, accompanied with the reduced pro-inflammatory cytokines mRNA levels through RT-qPCR analysis (Fig. 12E). Additionally, anti-oxidants of SOD1, SOD2, CAT, HO-1 and Nrf2 were reduced in LPS treatment, contributing to ROS generation, while ST1926 enhanced these anti-oxidants with apparent difference in comparison to the LPS group (Fig. 12F). Next, TLR4/MyD88 signaling pathway was calculated, which was highly activated for LPS, leading to IKK $\alpha$ expression. ST1926 showed inhibitory role in TLR4, MyD88 and IKK $\alpha$ expression induced by LPS (Fig. 12G). NF-kB levels in the nucleus were increased by LPS, while decreased due to ST1926. Accordingly, IкB $\alpha$ and $\mathrm{p}-\mathrm{I} \kappa \mathrm{B} \alpha$ were also augmented in LPS single treatment group, in line with the results in MLE-12 cells mentioned

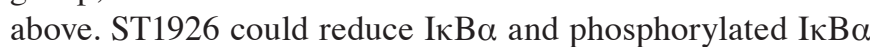
expression levels (Fig. 12H). Next, NHBE cells were exposed to LPS for different times as indicated to explore the p-p38 and p-ERK1/2 expression levels. Fig. 12J shows that p38 and ERK $1 / 2$ were activated due to LPS treatment, indicating ROS generation. With the increase of treatment time, the phosphorylation of $\mathrm{p} 38$ and ERK1/2 was maintained in high levels. Finally, p38 and ERK1/2 protein levels were assessed. As shown in Fig. 12I, phophorylated p38 and ERK1/2 were highly expressed in LPS-treated group, which were 
reduced by ST1926. In NHBE cells, we found similar results that ST1926 could reduce LPS-induced p38 and ERK1/2 phosphorylation beginning from $12 \mathrm{~h}$ with significant difference (Fig. 12K). Thus, the data above indicated that ST1926 could reduce LPS-induced p38 and ERK1/2 phosphorylation from 12 or $18 \mathrm{~h}$ in a time-dependent manner.

\section{Discussion}

Acute lung injury (ALI) is a severe disease syndrome, which consists of hypoxemic respiratory failure accompanied by bilateral pulmonary infiltrates, and has been considered as a serious threat for people, especially children with relatively weak immune system $(1,2,40,41)$. Furthermore, as the acute respiratory distress syndrome, the formation and development of ALI is linked to high morbidity and mortality (42). According to previous studies, many therapeutic strategies were investigated and used to prevent acute lung injury in children (43). However, more effective approach and the possible molecular mechanism is still needed to be explored.

Natural retinoids such as all-trans retinoic acid are currently used as important therapeutic agents in human diseases, mainly acute promyelocytic leukemia $(44,45)$. Synthetic retinoid of ST1926 has been developed to overcome resistance and attenuate side effects. ST1926 has the same crucial structural and pharmacological groups as CD437, the lipophilic adamantyl moiety, and the carboxylic function. However, ST1926 was designed to be with a styrene moiety replacing the naphthalene ring of CD437, leading to a pharmacokinetically stable, highly orally bioavailable, as well as pharmacologically attainable in plasma of patients at the micromolar concentrations $(21,22)$. ST1926 has been suggested to induce apoptosis in tumor cells, which was related to anti-apoptotic Bcl-2 protein suppression (46). Bcl-2 is known to be upregulated in NF- $\mathrm{kB}$ activation (47). Thus, we supposed that ST1926 may have a possible effect on NF- $\mathrm{KB}$ suppression. NF- $\mathrm{KB}$ is well known to modulate inflammation response. Hence, ST1926 was chosen in our study to explore if it could be used in treating lung injury, providing a new therapeutic strategy for acute lung injury. In this study, ST1926 showed downregulated role in inflammation infiltration, suggesting that ST1926 may have a potential effect on controlling inflammation response in acute lung injury related to the immune system.

As we mentioned above, inflammation response is well known to play an essential role in various disease development, including cancers, diabetes, as well as lung injury in different forms (48). Neutrophils and macrophages were the main inflammatory cells in acute lung injury. They infiltrated into the lung tissues, releasing enzymes and phagocytizing the pathogen. These inflammatory cells were the fundamental source of inflammatory mediators in vivo. In LPS-induced inflammation, neutrophils and macrophages were activated (49). After activation, neutrophils and macrophages were recruited to the inflammation site (50). Lymphocytes have drawn increased attention, and there is accumulating evidence indicating that lymphocytes play important roles in the development of acute lung injury. It has been suggested that lymphocytes contribute to the progression of autoimmune and inflammatory diseases (51). In our study, we found that LPS upregulated lymphocytes, neutrophils and macrophages, contributing to inflammation response, which could be reversed by ST1926 administration. Additionally, pro-inflammatory cytokines, including TNF- $\alpha$, IL-1 $\beta$, IL-18, IL- 6 and IL-17, are main factors causing inflammatory response, and their activation is a key to accelerate disease progression (52). In this study, we found that LPS induced higher expression of these pro-inflammatory cytokines, was in line with a previous report in acute lung injury caused by LPS $(53,54)$. However, ST1926 showed significantly suppressive role in controlling the cytokine secretion, inhibiting inflammation. Inflammatory cytokine release could be stimulated by NF- $\mathrm{KB}$ phosphorylation, which is dependent on IKK $\alpha$ and IKB $\alpha$ signaling pathway activation (55). Consistently, in our present study, we found that IKK $\alpha$ and IкB $\alpha$ were upregulated in LPS treatment in vivo and in vitro, subsequently contributing to NF- $\mathrm{kB}$ phosphorylation and pro-inflammatory cytokines secretion eventually, which may be a main cause, leading to lung injury in animal models

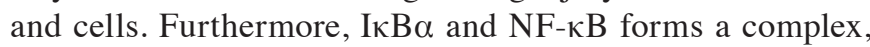
inhibiting NF- $\mathrm{KB}$ translocation into nuclear and suppressing pro-inflammatory cytokines release. In contrast, phosphorylated $\mathrm{I} \kappa \mathrm{B} \alpha$ abolished the $\mathrm{I} \kappa \mathrm{B} \alpha / \mathrm{NF}-\kappa \mathrm{B}$ complex, promoting $\mathrm{NF}-\kappa \mathrm{B}$ translocation into nuleus and causing inflammatory response $(56,57)$. In line with a previous study, we found that $\mathrm{NF}-\kappa \mathrm{B}$ levels in nucleus were promoted in LPS treatment, consistent to cytoplasmic p-NF- $\mathrm{kB}$ alteration in, leading to inflammation response. Obviously, ST1926 had a significant role in reducing nuclear NF- $\mathrm{KB}$, subsequently suppressing proinflammatory cytokine secretion. Additionally, the cytoplasm I $\kappa \alpha$ levels were increased for LPS treatment, while p-IкB $\alpha$ was decreased. ST1926 downregulated $\mathrm{I} \kappa \mathrm{B} \alpha$ and $\mathrm{p}-\mathrm{I} \kappa \mathrm{B} \alpha$ levels. Thus, ST1926 could improve inflammation response by preventing NF- $\kappa B$ translocation into the nucleus. Toll-like receptor-4 (TLR-4) could identify pathogenic microorganisms in a natural immune system, bind the specific ligand and generate corresponding inflammation following identification $(58,59)$. TLR-4 exogenous ligands include LPS. Here, we also found that TLR4/MyD88 signaling pathway was highly activated by LPS induction, which was consistent with NF- $\mathrm{BB}$ activity. ST1926 apparently downregulated TLR4 and MyD88 expression levels after LPS induction, revealing that TLR4 was also involved in ST1926-improved lung injury.

Oxidative stress is widely involved in progression of many diseases (60). SOD and CAT are two typical anti-oxidants, representing oxidative stress level (61). SOD is well known as an essential anti-oxidase that converses $\mathrm{O}_{2}{ }^{-}$into $\mathrm{O}_{2}$ and $\mathrm{H}_{2} \mathrm{O}_{2}$ (62). CAT could catalyze $\mathrm{H}_{2} \mathrm{O}_{2}$ into $\mathrm{H}_{2} \mathrm{O}$ and $\mathrm{O}_{2}$, reducing ROS generation (63). Additionally, phase II detoxifying enzymes such as HO-1 is also known as an effective antioxidant enzyme (64). HO-1, encoded by HMOX1 gene, can change haeme into the strong pro-oxidant biliverdin, which is subsequently transformed into bilirubin, a potent antioxidant (65). Nuclear factor erythroid 2 related factor 2 (Nrf2), a key regulator of antioxidant defense system, protects cells against oxidative stress (66). Downregulated SOD, CAT, HO-1 and Nrf2 for LPS were found to be upregulated after ST1926 treatment. In contrast, LPS-induced higher levels of MDA and ROS species of $\mathrm{O}_{2}^{-}$and $\mathrm{H}_{2} \mathrm{O}_{2}$ were decreased in ST1926-treated groups. Also, according to previous studies, an inverse correlation was observed between anti-oxidant mRNA and ROS levels. With the increase of anti-oxidant expression via $\mathrm{Nrf}-2 / \mathrm{HO}-1$ 
pathway, the ROS generation was accordingly reduced, proved by downregulated $\mathrm{O}_{2}, \mathrm{H}_{2} \mathrm{O}_{2}, \mathrm{NO}, \mathrm{MPO}$ and iNOS levels. In this study, similar results were observed, displaying an inverse correlation between anti-oxidant and ROS levels $(61,63,64)$. In addition, p38/ERK1/2 signaling pathway has a close relationship with ROS generation $(67,68)$. Following previous studies, p38/ERK1/2 signaling pathway is activated, contributing to oxidative stress progression in different injuries (69). Similarly, here we found that LPS induction caused higher ROS production. Interestingly, ST1926 displayed significant inhibitory role in controlling ROS production. AMP-activated protein kinase (AMPK) is a serine/threonine protein kinase that serves as an energy sensor in the regulation of cellular metabolism. Additionally, AMPK is reported to be closely associated with ROS production (70). AMPK is activated by changes in the AMP:ATP ratio that occur in response to energetic stress, and activation requires the phosphorylation of Thr172. Promotion of AMPK decreased ROS generation to improve injuries (71). AMPK phosphorylated levels were significantly reduced by LPS, and ST1926 augmented AMPK phosphorylation of Thr172, indicating ROS suppression by ST1926. Collectively, our data indicated that ST1926 was associated with LPS-induced acute lung injury progression via TLR4/NF- $\mathrm{BB}$ and AMPK/p38/ ERK1/2 signaling suppression.

In conclusion, the results above showed that LPS-induced acute lung injury in mice was developed from inflammation activation and ROS generation in lung tissue samples and epithelial cells through TLR4/NF- $\mathrm{B}$ and p38/ERK1/2 pathways. This study elucidated the possible mechanism by which ST1926 attenuated acute lung injury with little toxicity, which may be a potential therapy for acute lung injury for children.

\section{Acknowledgements}

Not applicable.

\section{Funding}

No funding was received.

\section{Availability of data and material}

The datasets used and/or analyzed during the current study are available from the corresponding author on reasonable request.

\section{Authors' contributions}

ZD designed the project and wrote the paper. YY performed the lab experiment and data analysis. Both authors read and approved the final manuscript.

\section{Ethics approval and consent to participate}

This study was approved by the Ethics Committee on Animal Research at the Department of Pediatrics, Huai'an First People's Hospital, Nanjing Medical University, Nanjing, China.

\section{Consent for publication}

Not applicable.

\section{Competing interests}

The authors declare that they have no competing interests.

\section{References}

1. Pediatric Acute Lung Injury Consensus Conference Group: Pediatric acute respiratory distress syndrome: Consensus recommendations from the Pediatric Acute Lung Injury Consensus Conference. Pediatr Crit Care Med 16: 428-439, 2015.

2. Rettig JS, Smallwood CD, Walsh BK, Rimensberger PC, Bachman TE, Bollen CW, Duval EL, Gebistorf F, Markhorst DG, Tinnevelt $\mathrm{M}$, et al: High-frequency oscillatory ventilation in pediatric acute lung injury: A multicenter international experience. Crit Care Med 43: 2660-2667, 2015.

3. Thomas NJ, Jouvet P and Willson D: Acute lung injury in children - kids really aren't just 'little adults'. Pediatr Crit Care Med 14: 429-432, 2013.

4. López-Fernández Y, Azagra AM, de la Oliva P, Modesto V, Sánchez JI, Parrilla J, Arroyo MJ, Reyes SB, Pons-Odena M, López-Herce J, et al; Pediatric Acute Lung Injury Epidemiology and Natural History (PED-ALIEN) Network: Pediatric acute lung injury epidemiology and natural history study: Incidence and outcome of the acute respiratory distress syndrome in children. Crit Care Med 40: 3238-3245, 2012.

5. Zhang B, Liu ZY, Li YY, Luo Y, Liu ML, Dong HY, Wang YX, Liu Y, Zhao PT, Jin FG, et al: Antiinflammatory effects of matrine in LPS-induced acute lung injury in mice. Eur J Pharm Sci 44: 573-579, 2011.

6. Santschi M, Randolph AG, Rimensberger PC and Jouvet P. Pediatric Acute Lung Injury Mechanical Ventilation Investigators; Pediatric Acute Lung Injury and Sepsis Investigators Network; European Society of Pediatric and Neonatal Intensive Care: Mechanical ventilation strategies in children with acute lung injury: A survey on stated practice pattern. Pediatr Crit Care Med 14: e332-e337, 2013.

7. Hernu R, Wallet F, Thiollière F, Martin O, Richard JC, Schmitt Z, Wallon G, Delannoy B, Rimmelé T, Démaret C, et al: An attempt to validate the modification of the American-European consensus definition of acute lung injury/acute respiratory distress syndrome by the Berlin definition in a university hospital. Intensive Care Med 39: 2161-2170, 2013.

8. Yehya N, Servaes S and Thomas NJ: Characterizing degree of lung injury in pediatric acute respiratory distress syndrome. Crit Care Med 43: 937-946, 2015.

9. Valentine SL, Sapru A, Higgerson RA, Spinella PC, Flori HR, Graham DA, Brett M, Convery M, Christie LM, Karamessinis L, et al; Pediatric Acute Lung Injury and Sepsis Investigator's (PALISI) Network; Acute Respiratory Distress Syndrome Clinical Research Network (ARDSNet): Fluid balance in critically ill children with acute lung injury. Crit Care Med 40: 2883-2889, 2012.

10. Hoesel B and Schmid JA: The complexity of NF- $\mathrm{kB}$ signaling in inflammation and cancer. Mol Cancer 12: 86, 2013.

11. Fu Y, Liu B, Zhang N, Liu Z, Liang D, Li F, Cao Y, Feng X, Zhang $X$ and Yang Z: Magnolol inhibits lipopolysaccharideinduced inflammatory response by interfering with TLR4 mediated $\mathrm{NF}-\kappa \mathrm{B}$ and MAPKs signaling pathways. J Ethnopharmacol 145: 193-199, 2013.

12. Wang Y, Tu Q, Yan W, Xiao D, Zeng Z, Ouyang Y, Huang L, Cai J, Zeng X, Chen YJ, et al: CXC195 suppresses proliferation and inflammatory response in LPS-induced human hepatocellular carcinoma cells via regulating TLR4-MyD88TAK1-mediated NF- $\kappa$ B and MAPK pathway. Biochem Biophys Res Commun 456: 373-379, 2015.

13. Capiralla H, Vingtdeux V, Zhao H, Sankowski R, Al-Abed Y, Davies P and Marambaud P: Resveratrol mitigates lipopolysaccharide- and $\mathrm{A} \beta$-mediated microglial inflammation by inhibiting the TLR4/NF-кB/STAT signaling cascade. J Neurochem 120: 461-472, 2012.

14. Wang W, Xia T and Yu X: Wogonin suppresses inflammatory response and maintains intestinal barrier function via TLR4-MyD88-TAK1-mediated NF- $\kappa \mathrm{B}$ pathway in vitro. Inflamm Res 64: 423-431, 2015.

15. Valavanidis A, Vlachogianni T, Fiotakis $\mathrm{K}$ and Loridas $\mathrm{S}$ : Pulmonary oxidative stress, inflammation and cancer: Respirable particulate matter, fibrous dusts and ozone as major causes of lung carcinogenesis through reactive oxygen species mechanisms. Int J Environ Res Public Health 10: 3886-3907, 2013. 
16. Fratelli M, Fisher JN, Paroni G, Di Francesco AM, Pierri F, Pisano C, Godl K, Marx S, Tebbe A, Valli C, et al: New insights into the molecular mechanisms underlying sensitivity/resistance to the atypical retinoid ST1926 in acute myeloid leukaemia cells: The role of histone H2A.Z, cAMP-dependent protein kinase A and the proteasome. Eur J Cancer 49: 1491-1500, 2013.

17. El Hajj H, Khalil B, Ghandour B, Nasr R, Shahine S, Ghantous A, Abdel-Samad R, Sinjab A, Hasegawa H, Jabbour M, et al: Preclinical efficacy of the synthetic retinoid ST1926 for treating adult T-cell leukemia/lymphoma. Blood 124: 2072-2080, 2014.

18. Di Francesco AM, Cusano G, Franzese O, Orienti I, Falconi M, Vesci L and Riccardi R: Resistance to the atypical retinoid ST1926 in SK-N-AS cells selected the subline rAS-ST with enhanced sensitivity to ATRA mediated by not conventional mechanisms: DNA damage, G2 accumulation and late telomerase inhibition. Toxicol In Vitro 29: 1628-1638, 2015.

19. Zuco V, Benedetti V, De Cesare M and Zunino F: Sensitization of ovarian carcinoma cells to the atypical retinoid ST1926 by the histone deacetylase inhibitor, RC307: Enhanced DNA damage response. Int J Cancer 126: 1246-1255, 2010.

20. Bernasconi E, Gaudio E, Kwee I, Rinaldi A, Cascione L, Tarantelli C, Mensah AA, Stathis A, Zucca E, Vesci L, et al: The novel atypical retinoid ST5589 downregulates Aurora Kinase A and has anti-tumour activity in lymphoma pre-clinical models. Br J Haematol 171: 378-386, 2015.

21. Basma H, Ghayad SE, Rammal G, Mancinelli A, Harajly M, Ghamloush F, Dweik L, El-Eit R, Zalzali H, Rabeh W, et al: The synthetic retinoid ST1926 as a novel therapeutic agent in rhabdomyosarcoma. Int J Cancer 138: 1528-1537, 2016.

22. Sala F, Zucchetti M, Bagnati R, D'Incalci M, Pace S, Capocasa F and Marangon E: Development and validation of a liquid chromatography-tandem mass spectrometry method for the determination of ST1926, a novel oral antitumor agent, adamantyl retinoid derivative, in plasma of patients in a phase 1 study. J Chromatogr B Analyt Technol Biomed Life Sci 877: 3118-3126, 2009.

23. Pisano C, Vesci L, Foderà R, Ferrara FF, Rossi C, De Cesare M, Zuco V, Pratesi G, Supino R and Zunino F: Antitumor activity of the combination of synthetic retinoid ST1926 and cisplatin in ovarian carcinoma models. Ann Oncol 18: 1500-1505, 2007.

24. González-Terán B, Cortés JR, Manieri E, Matesanz N, Verdugo Á, Rodríguez ME, González-Rodríguez Á, Valverde ÁM, Martín P, Davis RJ, et al: Eukaryotic elongation factor 2 controls TNF- $\alpha$ translation in LPS-induced hepatitis. J Clin Invest 123: 164-178, 2013.

25. Akbarshahi H, Sam A, Chen C, Rosendahl AH and Andersson R: Early activation of pulmonary TGF- $\beta 1 / \mathrm{Smad} 2$ signaling in mice with acute pancreatitis-associated acute lung injury. Mediators Inflamm 2014: 148029, 2014

26. Hirota JA, Hiebert PR, Gold M, Wu D, Graydon C, Smith JA Ask K, McNagny K, Granville DJ and Knight DA: Granzyme B deficiency exacerbates lung inflammation in mice after acute lung injury. Am J Respir Cell Mol Biol 49: 453-462, 2013.

27. Nieves W, Hung LY, Oniskey TK, Boon L, Foretz M, Viollet B and Herbert DR: Myeloid-restricted AMPK $\alpha 1$ promotes host immunity and protects against IL-12/23p40-dependent lung injury during hookworm infection. J Immunol 196: 4632-4640, 2016.

28. Glista-Baker EE, Taylor AJ, Sayers BC, Thompson EA and Bonner JC: Nickel nanoparticles cause exaggerated lung and airway remodeling in mice lacking the T-box transcription factor, TBX21 (T-bet). Part Fibre Toxicol 11: 7, 2014.

29. Do-Umehara HC, Chen C, Urich D, Zhou L, Qiu J, Jang S, Zander A, Baker MA, Eilers M, Sporn PH, et al: Suppression of inflammation and acute lung injury by Miz1 via repression of C/EBP- $\delta$. Nat Immunol 14: 461-469, 2013.

30. Kuchroo VK, Wu C, Pot C, Apetoh L and Anderson AC: Methods for modulating immune responses during chronic immune conditions by targeting metallothioneins: US Patent Application WO 2014172606 A1. Filed April 18, 2014; issued October 23, 2014.

31. Wang Y, Wang H, Zhang W, Shao C, Xu P, Shi CH, Shi JG, Li YM, Fu Q, Xue W, et al: Genistein sensitizes bladder cancer cells to HCPT treatment in vitro and in vivo via $\mathrm{ATM} / \mathrm{NF}-\kappa \mathrm{B} /$ IKK pathway-induced apoptosis. PLoS One 8: e50175, 2013.

32. Zhu HT, Bian C, Yuan JC, Chu WH, Xiang X, Chen F, Wang CS, Feng $\mathrm{H}$ and Lin JK: Curcumin attenuates acute inflammatory injury by inhibiting the TLR4/MyD88/NF- $\kappa \mathrm{B}$ signaling pathway in experimental traumatic brain injury. J Neuroinflammation 11: $59,2014$.
33. Arslan F, Lai RC, Smeets MB, Akeroyd L, Choo A, Aguor EN, Timmers L, van Rijen HV, Doevendans PA, Pasterkamp G, et al: Mesenchymal stem cell-derived exosomes increase ATP levels, decrease oxidative stress and activate PI3K/Akt pathway to enhance myocardial viability and prevent adverse remodeling after myocardial ischemia/reperfusion injury. Stem Cell Res 10: 301-312, 2013.

34. de Lima FM, Albertini R, Dantas Y, Maia-Filho AL, Santana Cde L, Castro-Faria-Neto HC, França C, Villaverde AB and Aimbire F: Low-level laser therapy restores the oxidative stress balance in acute lung injury induced by gut ischemia and reperfusion. Photochem Photobiol 89: 179-188, 2013.

35. Golden T, Crabtree M, Channon K and Gow AJ: Uncoupled inducible nitric oxide synthase influences macrophage polarization in acute lung injury. Am J Respir Crit Care Med 193: A2651-A2651, 2016

36. Tsai CL, Lin YC, Wang HM and Chou TC: Baicalein, an active component of Scutellaria baicalensis, protects against lipopolysaccharide-induced acute lung injury in rats. J Ethnopharmacol 153: 197-206, 2014.

37. Barut F, Ozacmak VH, Turan I, Sayan-Ozacmak H and Aktunc E: Reduction of acute lung injury by administration of spironolactone after intestinal ischemia and reperfusion in rats. Clin Invest Med 39: E15-E24, 2016.

38. Koinzer S, Reinecke K, Herdegen T, Roider J and Klettner A: Oxidative stress induces biphasic ERK1/2 activation in the RPE with distinct effects on cell survival at early and late activation. Curr Eye Res 40: 853-857, 2015.

39. Cheng PW, Ho WY, Su YT, Lu PJ, Chen BZ, Cheng WH, Lu WH, Sun GC, Yeh TC, Hsiao M, et al: Resveratrol decreases fructoseinduced oxidative stress, mediated by NADPH oxidase via an AMPK-dependent mechanism. Br J Pharmacol 171: 2739-2750, 2014.

40. Acute Respiratory Distress Syndrome Network, Brower RG, Matthay MA, Morris A, Schoenfeld D, Thompson BT and Wheeler A: Ventilation with lower tidal volumes as compared with traditional tidal volumes for acute lung injury and the acute respiratory distress syndrome. N Engl J Med 342: 1301-1308, 2000.

41. Caudrillier A, Kessenbrock K, Gilliss BM, Nguyen JX, Marques MB, Monestier M, Toy P, Werb Z and Looney MR: Platelets induce neutrophil extracellular traps in transfusionrelated acute lung injury. J Clin Invest 122: 2661-2671, 2012.

42. Li YW, Zhang Y, Zhang L, Li X, Yu JB,Zhang HT, Tan BB, Jiang LH, Wang YX, Liang Y, et al: Protective effect of tea polyphenols on renal ischemia/reperfusion injury via suppressing the activation of TLR4/NF-kB p65 signal pathway. Gene 542: 46-51, 2014.

43. Lieberman L, Petraszko T, Yi QL, Hannach B and Skeate R: Transfusion-related lung injury in children: A case series and review of the literature. Transfusion 54: 57-64, 2014.

44. Niu H, Chacko J, Hadwiger G and Welch JS: Absence of natural intracellular retinoids in mouse bone marrow cells and implications for PML-RARA transformation. Blood Cancer J 5: e284, 2015.

45. Morriss-Kay G, Ward S and Sokolova N: The role of retinoids in normal development. In: Use of Mechanistic Information in Risk Assessment: Proceedings of the 1993 EUROTOX Congress Meeting Held in Uppsala, Sweden, June 30-July 3, 1993. Springer Science and Business Media, 2012, 16: 112.

46. Di Francesco AM, Cusano G, Franzese O, Orienti I, Falconi M, Vesci L and Riccardi R: Resistance to the atypical retinoid ST1926 in SK-N-AS cells selected the subline rAS-ST with enhanced sensitivity to ATRA mediated by not conventional mechanisms: DNA damage, G2 accumulation and late telomerase inhibition. Toxicol In Vitro 29: 1628-1638, 2015.

47. Chiron D, Dousset C, Brosseau C, Touzeau C, Maïga S, Moreau P, Pellat-Deceunynck C, Le Gouill S and Amiot M: Biological rational for sequential targeting of Bruton tyrosine kinase and Bcl-2 to overcome CD40-induced ABT-199 resistance in mantle cell lymphoma. Oncotarget 6: 8750-8759, 2015.

48. Cani PD, Bibiloni R, Knauf C, Waget A, Neyrinck AM, Delzenne NM and Burcelin R: Changes in gut microbiota control metabolic endotoxemia-induced inflammation in high-fat dietinduced obesity and diabetes in mice. Diabetes 57: 1470-1481, 2008.

49. Hidalgo MA, Romero A, Figueroa J, Cortés P, Concha II, Hancke JL and Burgos RA: Andrographolide interferes with binding of nuclear factor-kappaB to DNA in HL-60-derived neutrophilic cells. Br J Pharmacol 144: 680-686, 2005.

50. Lee L, Kelher MR, Moore EE, Banerjee A and Silliman CC: Hypertonic saline inhibits arachidonic acid priming of the human neutrophil oxidase. J Surg Res 174: 24-28, 2012. 
51. Noack $\mathrm{M}$ and Miossec P: Th17 and regulatory T cell balance in autoimmune and inflammatory diseases. Autoimmun Rev 13: 668-677, 2014.

52. Pasarica M, Sereda OR, Redman LM, Albarado DC, Hymel DT, Roan LE, Rood JC, Burk DH and Smith SR: Reduced adipose tissue oxygenation in human obesity: Evidence for rarefaction, macrophage chemotaxis, and inflammation without an angiogenic response. Diabetes 58: 718-725, 2009.

53. Xu CQ, Liu BJ, Wu JF, Xu YC, Duan XH, Cao YX and Dong JC: Icariin attenuates LPS-induced acute inflammatory responses: Involvement of PI3K/Akt and NF-kappaB signaling pathway. Eur J Pharmacol 642: 146-153, 2010.

54. Schwartz EA, Zhang WY, Karnik SK, Borwege S, Anand VR, Laine PS, Su Y and Reaven PD: Nutrient modification of the innate immune response: A novel mechanism by which saturated fatty acids greatly amplify monocyte inflammation. Arterioscler Thromb Vasc Biol 30: 802-808, 2010.

55. Hayden MS and Ghosh S: Shared principles in NF-kappaB signaling. Cell 132: 344-362, 2008.

56. Jia Z, Nallasamy P, Liu D, Shah H, Li JZ, Chitrakar R, Si H, McCormick J, Zhu H, Zhen W, et al: Luteolin protects against vascular inflammation in mice and TNF-alpha-induced monocyte adhesion to endothelial cells via suppressing $\mathrm{I} \kappa \mathrm{B} \alpha / \mathrm{NF}-\kappa \mathrm{B}$ signaling pathway. J Nutr Biochem 26: 293-302, 2015.

57. Manna P, Ghosh M, Ghosh J, Das J and Sil PC: Contribution of nano-copper particles to in vivo liver dysfunction and cellular damage: Role of $\mathrm{I} \kappa \mathrm{B} \alpha / \mathrm{NF}-\kappa \mathrm{B}, \mathrm{MAPKs}$ and mitochondrial signal. Nanotoxicology 6: 1-21, 2012.

58. Kawai T and Akira S: Signaling to NF-kappaB by Toll-like receptors. Trends Mol Med 13: 460-469, 2007.

59. Baker RG, Hayden MS and Ghosh S: NF- $\mathrm{BB}$, inflammation, and metabolic disease. Cell Metab 13: 11-22, 2011.

60. Chouchani ET, Pell VR, Gaude E, Aksentijević D, Sundier SY, Robb EL, Logan A, Nadtochiy SM, Ord EN, Smith AC, et al: Ischaemic accumulation of succinate controls reperfusion injury through mitochondrial ROS. Nature 515: 431-435, 2014.

61. Lipovsky A, Nitzan Y, Gedanken A and Lubart R: Antifungal activity of $\mathrm{ZnO}$ nanoparticles - the role of ROS mediated cell injury. Nanotechnology 22: 105101, 2011.

62. Beladi-Mousavi SS, Hajibabaei K, Tamadon MR and RafieianKopaei M: Relationship between free radicals and risk of kidney diseases; the role of antioxidants and their reaction mechanisms. Ann Res Antioxid 1: e02, 2016.

63. Sousa RHV, Carvalho FEL, Ribeiro CW, Passaia G, Cunha JR, Lima-Melo Y, Margis-Pinheiro M and Silveira JA: Peroxisomal APX knockdown triggers antioxidant mechanisms favourable for coping with high photorespiratory $\mathrm{H}_{2} \mathrm{O}_{2}$ induced by CAT deficiency in rice. Plant Cell Environ 38: 499-513, 2015.
64. Kusunoki C, Yang L, Yoshizaki T, Nakagawa F, Ishikado A, Kondo M, Morino K, Sekine O, Ugi S, Nishio Y, et al: Omega-3 polyunsaturated fatty acid has an anti-oxidant effect via the Nrf-2/HO-1 pathway in 3T3-L1 adipocytes. Biochem Biophys Res Commun 430: 225-230, 2013.

65. Kah J, Volz T, Lütgehetmann M and Dandri M: Hemoxygenase-1 and its downstream product Biliverdin suppress HCV replication and provides hepatoprotective effects in humanized uPA/SCID mice. Zeitschrift für Gastroenterologie 52: 5-17, 2014.

66. Staitieh BS, Ding L, Neveu WA, Spearman P, Guidot DM and Fan X: HIV-1 decreases Nrf2/ARE activity and phagocytic function in alveolar macrophages. J Leukoc Biol: May 26, 2017. (Epub ahead of print). doi: 10.1189/jlb.4A0616-282RR.

67. Sun WH, Liu F, Chen Y and Zhu YC: Hydrogen sulfide decreases the levels of ROS by inhibiting mitochondrial complex IV and increasing SOD activities in cardiomyocytes under ischemia/reperfusion. Biochem Biophys Res Commun 421: 164-169, 2012.

68. Lan A, Liao X, Mo L, Yang C, Yang Z, Wang X, Hu F, Chen P, Feng J, Zheng D, et al: Hydrogen sulfide protects against chemical hypoxia-induced injury by inhibiting ROS-activated ERK1/2 and p38MAPK signaling pathways in PC12 cells. PLoS One 6: e25921,2011.

69. Choi DC, Lee JY, Lim EJ, Baik HH, Oh TH and Yune TY: Inhibition of ROS-induced p38MAPK and ERK activation in microglia by acupuncture relieves neuropathic pain after spinal cord injury in rats. Exp Neurol 236: 268-282, 2012.

70. Cheng PW, Ho WY, Su YT, Lu PJ, Chen BZ, Cheng WH, Lu WH, Sun GC, Yeh TC, Hsiao M, et al: Resveratrol decreases fructoseinduced oxidative stress, mediated by NADPH oxidase via an AMPK-dependent mechanism. Br J Pharmacol 171: 2739-2750, 2014.

71. Cheng PW, Lee HC, Lu PJ, Chen HH, Lai CC, Sun GC, Yeh TC, Hsiao M, Lin YT, Liu CP, et al: Resveratrol inhibition of Rac1-derived reactive oxygen species by AMPK decreases blood pressure in a fructose-induced rat model of hypertension. Sci Rep 6: 25342, 2016.

This work is licensed under a Creative Commons Attribution-NonCommercial-NoDerivatives 4.0 International (CC BY-NC-ND 4.0) License. 